\title{
Menthol Stereoisomers Exhibit Different Effects on $\alpha 4 \beta 2$ nAChR Upregulation and Dopamine Neuron Spontaneous Firing
}

\author{
(DBandon J. Henderson, ${ }^{1,2 *}$ 'DStephen Grant, ${ }^{3 *}$ Betty K. Wong, ${ }^{1 *}$ Rezvan Shahoei, ${ }^{4}$ (D) Stephanie M.
} Huard, ${ }^{1}$ Shyam S. M. Saladi, ${ }^{3}$ Emad Tajkhorshid, ${ }^{5}$ Dennis A. Dougherty, ${ }^{3}$ and ${ }^{\mathbb{O}}$ Henry A. Lester ${ }^{1}$

https://doi.org/10.1523/ENEURO.0465-18.2018

${ }^{1}$ Division of Biology and Biological Engineering, California Institute of Technology, Pasadena, California 91125, ${ }^{2}$ Department of Biomedical Sciences, Joan C. Edwards School of Medicine at Marshall University, Huntington, West Virginia 25703, ${ }^{3}$ Division of Chemistry and Chemical Engineering, California Institute of Technology, Pasadena, California 91125, ${ }^{4}$ Department of Physics, National Institutes of Health Center for Macromolecular Modeling and Bioinformatics, Beckman Institute for Advanced Science and Technology, University of Illinois at Urbana-Champaign, Urbana, Illinois 61801, and ${ }^{5}$ Department of Biochemistry, National Institutes of Health Center for Macromolecular Modeling and Bioinformatics, Beckman Institute for Advanced Science and Technology, Center for Biophysics and Quantitative Biology, University of Illinois at Urbana-Champaign, Urbana, Illinois 61801

\begin{abstract}
Menthol contributes to poor cessation rates among smokers, in part because menthol enhances nicotine reward and reinforcement. Mentholated tobacco products contain (-)-menthol and (+)-menthol, in varying proportions. We examined these two menthol stereoisomers for their ability to upregulate $\alpha 4 \beta 2 \mathrm{nAChRs}$ and to alter dopamine neuron firing frequency using long-term, low-dose ( $\leq 500 \mathrm{~nm}$ ) exposure that is pharmacologically relevant to smoking. We found that $(-)$-menthol upregulates $\alpha 4 \beta 2 \mathrm{nAChRs}$ while (+)-menthol does not. We also found that $(-)$-menthol decreases dopamine neuron baseline firing and dopamine neuron excitability, while (+)-menthol exhibits no effect. We then examined both stereoisomers for their ability to inhibit $\alpha 4 \beta 2 \mathrm{nAChR}$ function at higher concentrations $(>10 \mu \mathrm{M})$ using the Xenopus oocyte expression system. To probe for the potential binding site of menthol, we conducted flooding simulations and site-directed mutagenesis. We found that menthol likely binds to the 9' position on the TM2 (transmembrane M2) helix. We found that menthol inhibition is dependent on the end-to-end distance of the side chain at the 9' residue. Additionally, we have found that $(-)$-menthol is only modestly ( $25 \%$ ) more potent than (+)-menthol at inhibiting wild-type $\alpha 4 \beta 2 \mathrm{nAChRs}$ and a series of $\mathrm{L9}^{\prime}$ mutant nAChRs. These data reveal that menthol exhibits a stereoselective effect on nAChRs and that the stereochemical effect is much greater for long-term, submicromolar exposure in mice than for acute, higher-level exposure. We hypothesize that of the two menthol stereoisomers, only (-)-menthol plays a role in enhancing nicotine reward through nAChRs on dopamine neurons.
\end{abstract}

Key words: cigarettes; electronic nicotine delivery systems; nicotine; nicotine addiction; Xenopus oocyte

\section{Significance Statement}

Menthol is the most popular flavor used in all forms of tobacco products. Depending on the method used to produce the menthol, these products contain two stereoisomers [(-)-menthol and (+)-menthol] in unregulated and poorly characterized amounts. We studied how these isomers of menthol differ in their ability to alter nicotinic receptors on dopamine neurons that contribute to tobacco addiction. Long-term treatment with (-)-menthol and (+)-menthol resulted in a stereospecific effect on nicotinic receptor upregulation and dopamine neuron excitability: (+)-menthol exhibited no effect while (-)-menthol exhibited a robust effect. In acute treatments, we found only slight differences between the effects of the two isomers on nicotine receptors. This suggests that long-term exposure to (-)-menthol may contribute to exacerbating tobacco addiction. 


\section{Introduction}

Menthol cigarettes are used by a third of smokers and by the majority of African-American smokers (McCarthy et al., 1995). Smokers of menthol cigarettes are less likely to quit when compared with smokers of nonmenthol cigarettes (Ahijevych and Garrett, 2010). Youth smokers of menthol cigarettes are twice as likely to become lifelong smokers compared with youth smokers of nonmenthol cigarettes (D'Silva et al., 2012). Menthol is present in much of the electronic nicotine delivery system (ENDS) market (Centers for Disease Control and Prevention, 2016). Some countries, as well as some municipalities in the United States, ban menthol in combustible tobacco products. Apart from these exceptions, menthol holds a unique position as a tobacco flavoring: it is the only flavor allowed in combustible cigarettes in the United States following the 2009 Family Smoking Prevention and Tobacco Control Act.

Recent investigations of menthol identified pharmacological effects on several members of the Cys-loop family of receptors: menthol is (1) a negative allosteric modulator of $\alpha 4 \beta 2$ nAChRs, (2) a noncompetitive antagonist of $\alpha 7$ and $\alpha 3 \beta 4$ nAChRs, (3) a noncompetitive antagonist of $5-\mathrm{HT}_{3}$ receptors, (4) a positive allosteric modulator of $\mathrm{GABA}_{\mathrm{A}}$ receptors, and (5) a positive modulator of glycine receptors (Hall et al., 2004; Hans et al., 2012; Ashoor et al., 2013a, b; Lau and Vaughan, 2014; Ton et al., 2015). While most investigations examined (-)-menthol only, one identified a difference in the actions of $(+)$-menthol and (-)-menthol (Hall et al., 2004). Hall et al. (2004) observed that $(+)$-menthol is a potent allosteric potentiator of $\mathrm{GABA}_{\mathrm{A}}$-mediated currents, while (-)-menthol provided a modest enhancement.

Eight stereoisomers of menthol exist. Plants produce mainly the stereoisomer [1R, 2S, $5 R$ or (-)-menthol; Chen et al., 2011); but small quantities of additional stereoisomers occur in various types of mint leaves or in the extracted oil). As with many popular natural products, demand for menthol greatly exceeds the supply that can be obtained from plants. In the past, the primary synthetic

Received November 27, 2018; accepted December 8, 2018; First published December 21, 2018.

The authors declare no competing financial interests.

B.J.H., E.T., D.A.D., and H.A.L. designed experiments; B.J.H., S.G., B.W.C., R.S., S.M.H., and S.S.M.S. performed experiments; B.J.H., S.G., B.W.C., R.S., S.M.H., and S.S.M.S. analyzed data; B.J.H., S.G., E.T., and H.A.L. wrote the paper.

This research was supported by National Institutes of Health (NIH) Grants DA-036061, DA-037161, and DA-037743 (to H.A.L.); NIH Grants DA-033721 and DA-040047, and Marshall University Research Corporation (B.J.H.); and NIH Grants GM-104601, GM-087519, and GM-067887 (to R.S. and E.T.). Computing resources were provided by Blue Waters at the National Center for Supercomputing Applications and Extreme Science and Engineering Discovery Environment (XSEDE; Grant TG-MCA06N060 to E.T.).

${ }^{\star}$ B.J.H., S.G., and B.W.C. share co-first authorship.

Correspondence should be addressed to Henry A. Lester at Lester@caltech.edu. https://doi.org/10.1523/ENEURO.0465-18.2018

Copyright (C) 2018 Henderson et al.

This is an open-access article distributed under the terms of the Creative Commons Attribution 4.0 International license, which permits unrestricted use, distribution and reproduction in any medium provided that the original work is properly attributed. method for producing menthol used hydrogenation of pulegone, producing menthol as a racemate $[(+)$-menthol and (-)-menthol; Sell, 2006]. However, Ohkuma et al. (2000) developed an asymmetric synthesis method that provides pure (-)-menthol. Thus, while ( \pm )-menthol and $(+)$-menthol are easily produced synthetically and have been found in menthol tobacco products (Heck, 2010), (-)-menthol has now become the primary stereoisomer in tobacco products (Chen et al., 2011).

Previous data show that menthol by itself upregulates nAChRs (Alsharari et al., 2015; Henderson et al., 2016) and alters midbrain dopamine (DA) neuron firing (Henderson et al., 2016). Because both (+)-menthol and (-)menthol may be present in menthol cigarettes, we investigated the potential differences that these two stereoisomers may exhibit on $\mathrm{nAChR}$ upregulation and dopamine neuron firing. We show that only $(-)$-menthol is responsible for the upregulated $\alpha 4 \beta 2 \mathrm{nAChRs}$ and decreased dopamine neuron firing frequency found when neurons are treated with $( \pm)$-menthol. We also found that $(+)$-menthol is $25 \%$ less potent at inhibiting $\alpha 4 \beta 2$ nAChRs. The concentrations of menthol that inhibit $\alpha 4 \beta 2$ $\mathrm{nAChRs}$ are similar to the concentrations required to activate the TRPM8 (transient receptor potential cation channel subfamily $\mathrm{M}$ member 8 ) channel, which is mainly responsible for the cooling sensation elicited by menthol (Ha et al., 2015). We also investigated a putative binding site for menthol on $\alpha 4 \beta 2$ nAChRs using computational modeling and site-directed mutagenesis. Here we determined that menthol likely binds to the 9 ' site of the transmembrane M2 (TM2) helix of $\alpha 4 \mathrm{nAChR}$ subunits, and its binding interaction depends on steric interactions. Together, these data show that menthol exhibits different actions when applied in the long term or acutely. Longterm exposure to menthol exhibits a stereospecific effect on $\mathrm{nAChR}$ upregulation and dopamine neuron excitability: (-)-menthol produces a robust effect, and (+)-menthol seems to be inert. This suggests that (-)-menthol, and not $(+)$-menthol, possesses the potential risk of enhancing nicotine reward and reinforcement.

\section{Materials and Methods}

\section{Reagents}

(+)-Menthol (product number 63658), (-)-menthol (product number M2780), and ACh chloride (product number A6625) were obtained from Sigma-Aldrich.

\section{Mice and cultured midbrain neurons}

In electrophysiological experiments, we used pregnant female Gene Expression Nervous System Atlas tyrosine hydroxylase (TH)-eGFP mice (Henderson et al., 2016, 2017) that were purchased from the Mutant Mouse Regional Resource Center (Chapel Hill, NC). All experiments were conducted in accordance with the guidelines for the care and use of animals provided by the National Institutes of Health, and protocols were approved by the Institutional Animal Care and Use Committee at the California Institute of Technology. To culture primary midbrain neurons from the TH-eGFP mice, we used embryonic day 14 embryos. We did not determine the sex 
of the embryos; but, given the mixed population of males and females in litters, the resulting midbrain cultures were composed of neurons from both sexes. (without determining their sex). Ventral midbrain tissue was dissected and cultured using previously published procedures (Srinivasan et al., 2016). Following digestion with papain $\left(15 \mathrm{~min}\right.$ at $\left.37^{\circ} \mathrm{C}\right)$, cells were separated by DNase treatment and trituration, and were plated at a density of 100,000 cells/dish in poly-L-ornithine- and laminin-coated imaging dishes containing Neurobasal medium supplemented with B27, Glutamax, 1\% hyclone equine serum, and $100 \mu \mathrm{M}$ ascorbate. For drug treatments, control medium (control), $500 \mathrm{~nm}(-)$-menthol, or $500 \mathrm{~nm}(+)$-menthol were added to the cultures for $10 \mathrm{~d}$. Culture medium was changed at $\sim 3 \mathrm{~d}$ intervals.

\section{Neuro-2a cell culture and transient transfections}

Neuro-2a cells were cultured using standard techniques (Srinivasan et al., 2011). For imaging, cells were plated by adding 90,000 cells to poly-D-lysine-coated 35 $\mathrm{mm}$ glass-bottom imaging dishes (MatTek) and cultured in a humidified incubator $\left(37^{\circ} \mathrm{C}, 95 \%\right.$ air, $5 \% \mathrm{CO}_{2}$. Cells were transfected as described previously (Henderson et al., 2014). Similar to previous assays (Henderson et al., 2016), drug treatments (control or $500 \mathrm{~nm}$ menthol stereoisomers) were applied for $24 \mathrm{~h}$. Culture medium containing menthol was removed $1 \mathrm{~h}$ before the total internal reflection fluorescence microscopy (TIRFM) assays and replaced with extracellular solution (ECS), identical to methods previously described (Henderson et al., 2016, 2017).

\section{Total internal reflection fluorescence microscopy}

TIRFM enables the visualization of fluorescently labeled intracellular molecules on or near the plasma membrane (within $\sim 250 \mathrm{~nm}$ of the cell-coverslip interface). Cultured neuro-2a cells were imaged live at $37^{\circ} \mathrm{C}$ in a stagemounted culture dish incubator (Warner Instruments) using methods and instrumentation reported previously (Richards et al., 2011; Henderson et al., 2014). For each TIRFM session, image analysis was started $25 \mathrm{~h}$ after the beginning of drug treatment $(24 \mathrm{~h}$ for drug treatment, $1 \mathrm{~h}$ for washout with ECS). This ensured that each session recorded cells at the same time point. For each session and each drug condition, 30-40 cells were imaged. Each condition was measured in at least three separate imaging sessions.

\section{Patch-clamp electrophysiology}

Neurons were visualized with an upright microscope (BX50WI, Olympus) using near-infrared or blue illumination (the latter for visualizing GFP fluorescence). Wholecell patch-clamp techniques were used to record electrophysiological signals. Data were sampled at 10 $\mathrm{kHz}$ and filtered at $2 \mathrm{kHz}$. Patch electrodes had a resistance of 4-8 M $\Omega$, when filled with intracellular solution (in mM: $135 \mathrm{~K}$ gluconate, $5 \mathrm{KCl}, 5 \mathrm{EGTA}, 0.5 \mathrm{CaCl}_{2}, 10$ HEPES, $2 \mathrm{Mg}$-ATP, and $0.1 \mathrm{GTP})$. The ECS was composed as follows (in mM): $140 \mathrm{NaCl}, 5 \mathrm{KCl}, 2 \mathrm{CaCl}_{2}, 1$
$\mathrm{MgCl}_{2}, 10$ HEPES, and 10 glucose. The $\mathrm{pH}$ of these solutions was adjusted to 7.2 with Tris-base, and their osmolarity was adjusted to $300 \mathrm{mOsm}$ with sucrose.

All recordings were performed at a mean temperature of $32 \pm 1^{\circ} \mathrm{C}$. ACh $(300 \mu \mathrm{M})$ was puffed onto neurons using a Picospritzer III for a duration of $300 \mathrm{~ms}$ (holding levels: voltage clamp, $-65 \mathrm{mV}$; current clamp, $0 \mathrm{pA}$ ). Neurons were selected by the presence or absence of TH-eGFP fluorescence and labeled as putative DA or GABA neurons. Firing frequency and action potential duration were recorded ( $>1 \mathrm{~min}$ ) to further verify GFP or non-GFP distinctions of DA or GABA neurons. Drug treatments for cultured midbrain neurons were performed for $10 \mathrm{~d}$ (control or 500 nм either menthol stereoisomer; as described above). At the beginning of a recording session, dishes containing cultured midbrain neurons were rinsed with ECS to remove any remaining drug treatment. Cultured neurons were placed on the recording stage and perfused with ECS for $1 \mathrm{~h}$ to ensure that all remaining menthol from chronic treatments was removed. For all recording sessions, perfusion rates were maintained at constant flow so that changes in agonist washout did not complicate data interpretation.

\section{Oocyte preparation and injection}

Rat $\alpha 4$ and $\beta 2 \mathrm{nAChR}$ subunits were in pGEMhe vectors. The mRNAs were prepared from linearized DNA, using a T7 mMessage mMachine kit (Ambion) and were purified with the RNeasy Mini Kit (Qiagen). Xenopus laevis stage $\mathrm{V}$ and $\mathrm{VI}$ oocytes were harvested via standard protocols (Marotta et al., 2014). The $\alpha 4$ and $\beta 2$ mRNAs were mixed in a 1:10 ratio by mass to obtain the $(\alpha 4)_{2}(\beta 2)_{3}$ or in a 10:1 ratio to obtain the $(\alpha 4)_{3}(\beta 2)_{2}$ receptor. For unnatural amino acid incorporation, a TAG codon was incorporated into the site of interest, and $40 \mathrm{ng}$ of unnatural amino acid-coupled THG73 tRNA was added to the injection solution. The $\alpha 4$ and $\beta 2$ mRNAs were mixed in a $100: 1$ ratio by mass to obtain the $(\alpha 4)_{3}(\beta 2)_{2}$ receptor for these unnatural amino acid experiments. A total of $50 \mathrm{nl}$ of the RNA mixture were injected into each oocyte, delivering an mRNA mass total of $22 \mathrm{ng}$. After injection, the oocytes were incubated at $18^{\circ} \mathrm{C}$ in ND96 medium (see below) enriched with theophylline, sodium pyruvate, and gentamicin for $48 \mathrm{~h}$ before recording.

\section{Oocyte electrophysiology}

The OpusXpress 6000A (Molecular Devices) in twoelectrode voltage-clamp mode was used for all electrophysiological recordings. ACh was dissolved to $1 \mathrm{~m}$ stock solutions in $\mathrm{ND} 6 \mathrm{Ca}^{2+}$-free buffer $(96 \mathrm{mM} \mathrm{NaCl}, 2 \mathrm{~mm}$ $\mathrm{KCl}, 1 \mathrm{~mm} \mathrm{MgCl}{ }_{2}$, and $5 \mathrm{~mm}$ HEPES at $\mathrm{pH}$ 7.5). The holding potential was set to $-60 \mathrm{mV}$, and the running buffer used was ND96 $\mathrm{Ca}^{2+}$-free solution for all experiments. All drugs were applied as a $1 \mathrm{ml}$ application in ND96 $\mathrm{Ca}^{2+}$ buffer. Drug applications used $1 \mathrm{ml}$ of drug solution applied over $15 \mathrm{~s}$ followed by a $5 \mathrm{~min}$ buffer wash at a rate of $3 \mathrm{ml} / \mathrm{min}$. Data were sampled at $50 \mathrm{~Hz}$ and then low-pass filtered at $5 \mathrm{~Hz}$. Averaged and normalized data were fit to one Hill term to generate $\mathrm{EC}_{50}, \mathrm{IC}_{50}$, and Hill coefficient $\left(n_{H}\right)$ values. All currents for the activity testing were normalized to the maximum current pro- 
duced by the oocyte for a given compound $\left(I_{\max }\right)$ from ACh potentiation. The efficacy of compounds was measured as the ratio of the $I_{\max }$ of the compound divided by the $I_{\max }$ of the ACh. Error bars represent SEM values.

\section{Molecular dynamics simulations}

To characterize putative binding sites of menthol to the human $\alpha 4 \beta 2$ nicotinic receptor, flooding simulations were performed using NAMD 2.12 (Phillips et al., 2005). Flooding simulations are molecular dynamics (MD) simulations in which many identical molecules are initially placed in solution and allowed to diffuse and interact with the various environments such as water, membrane, and proteins.

For the protein structure, we used the $\mathrm{x}$-ray crystal structure of the human $\alpha 4 \beta 2$ nicotinic receptor (MoralesPerez et al., 2016; Protein Data Bank code, 5KXI). To prepare the protein for the simulation, we first used ModWeb (Sánchez and Sali, 1998), an automated comparative protein structure modeling web server, to build the missing intracellular loops (which connect M3 and M4 helices) for both $\alpha 4$ and $\beta 2$ subunits. Then, CHARMM-GUI (Jo et al., 2008) was used to embed the protein into a $120 \times$ $120 \AA$ POPC lipid bilayer in the $x-y$-plane. The $x$-ray crystal structure captures the receptor in its desensitized state with two nicotine molecules bound to the extracelIular domain of the receptor. In our simulation, we did not include the two bound nicotine molecules. To preserve the crystallographically captured state of the protein, we imposed harmonic restraints on backbone atoms over the course of the simulation. The SOLVATE and AUTOIONIZE plugins in VMD (Humphrey et al., 1996) were used to solvate and to ionize the system to an $\mathrm{NaCl}$ concentration of $150 \mathrm{~mm}$, respectively.

We started the flooding simulation with 178 menthol molecules (corresponding to a concentration of $\sim 165 \mathrm{~mm}$ ) randomly placed in the solution. In our preliminary simulations, the majority of menthol molecules aggregated in the solution before getting a chance to interact with the lipid head groups or the protein, an expected outcome given the highly hydrophobic nature of menthol $(\log \mathrm{D}=$ 2.7). To overcome this problem, nonbonded repulsive energy terms were introduced between the two oxygen atoms of each pair of menthol molecules (using NBFix corrections). We chose to decrease the well depth of the Lennard-Jones potential to $-0.10 \mathrm{kcal} / \mathrm{mol}$ instead of its original value of $-0.1921 \mathrm{kcal} / \mathrm{mol}$. We also increased the minimum interparticle distance between each pair of oxygen atoms from two menthol molecules from 3.53 to $12.00 \AA$. As a result, pairs of menthol molecules were prevented from aggregating. Given the NAMD cutoff of 12 $\AA$ for nonbonded interactions, by using these NBFix corrections, we basically turned off the attraction between any two oxygen atoms that belong to separate menthol molecules. The production run was performed for $800 \mathrm{~ns}$. After the first $350 \mathrm{~ns}$, the majority of menthol molecules partitioned into the membrane, allowing us to turn off the NBFix corrections so that multiple menthol molecules were not prevented from approaching the same binding site/region on the protein.
The simulations were performed under periodic boundary conditions. Long-range electrostatic interactions were calculated by the PME (Particle mesh Ewald method; Darden et al., 1993; Essmann et al., 1995) with one grid point density per angstrom. Except for the very first phase of melting the lipid tails, where the NVT (constant temperature, constant volume) ensemble is preferred, the NPT (constant temperature, constant pressure) ensemble was used. The constant temperature of $310 \mathrm{~K}$ for the system was provided by coupling it to a heat bath and through Langevin dynamics for all nonhydrogen atoms with a Langevin damping coefficient of $5 \mathrm{ps}^{-1}$. For the NPT simulation, the pressure was kept constant at 1 atmosphere through coupling to a Nosé-Hoover Langevin piston, with a period of $200 \mathrm{fs}$ and a damping timescale of 50 fs. Time steps of $2 \mathrm{fs}$ were chosen for the simulation. For the water molecules, the TIP3P model (Jorgensen et al., 1983) was used. CHARMM36 (Klauda et al., 2010) force field parameters were used for the protein, ions, and lipids. For menthol, we used the CHARMM General Force Field (CGenff; Vanommeslaeghe and MacKerell, 2012; Yu et al., 2012) charges and parameters, calculated by the CGenff web interface program (Vanommeslaeghe et al., 2010, 2012).

\section{Code and software availability}

NAMD 2.12 was used for all of the molecular dynamics simulations, and VMD was used for visualization and analysis of the simulation results. Both of these software packages are free and available for all users at https:// www.ks.uiuc.edu/Research/namd/ and at https://www.ks.uiuc.edu/Research/vmd/, respectively.

\section{Experimental design and statistical analysis}

All results are presented as the mean \pm SEM, and all statistical analyses were performed using GraphPad Prism. For microscopy assays (Fig. 1) and electrophysiology using cultured neurons (Figs. 2, 3), we used a power analysis (G*Power software, www.gpower.hhu.de) to determine appropriate sample sizes. In experiments that involved three or more group comparisons (Figs. 1-3), data were analyzed using a one-way or a two-way ANOVA. The choice of a one-way or two-way ANOVA is listed with the corresponding experiment in the Results section. When effects were shown to be significant, a post hoc analysis (Tukey's test) was performed to compare the individual group means.

\section{Results}

\section{Long-term effects of menthol stereoisomers cause different effects on $\alpha \mathbf{4} \beta 2 \mathrm{nAChR}$ upregulation}

A previous report found that $( \pm)$-menthol alone upregulates $\alpha 4 *$ and $\alpha 6 *$ nAChRs in cultured neuro-2a cells and mouse midbrain dopamine neurons (Henderson et al., 2016). In the previous report, $500 \mathrm{nM}( \pm)$-menthol achieved robust upregulation of $\alpha 4-$ SEP $\beta 2 \mathrm{nAChRs}$, while $50 \mathrm{~nm}( \pm)$-menthol had no effect (Henderson et al., 2016).

Similar to previous reports (Henderson et al., 2016, 2017), we used a combination of TIRFM and a $\mathrm{pH}$ sensitive GFP version of $\alpha 4$ nAChR subunits ( $\alpha 4$-SEP) to 

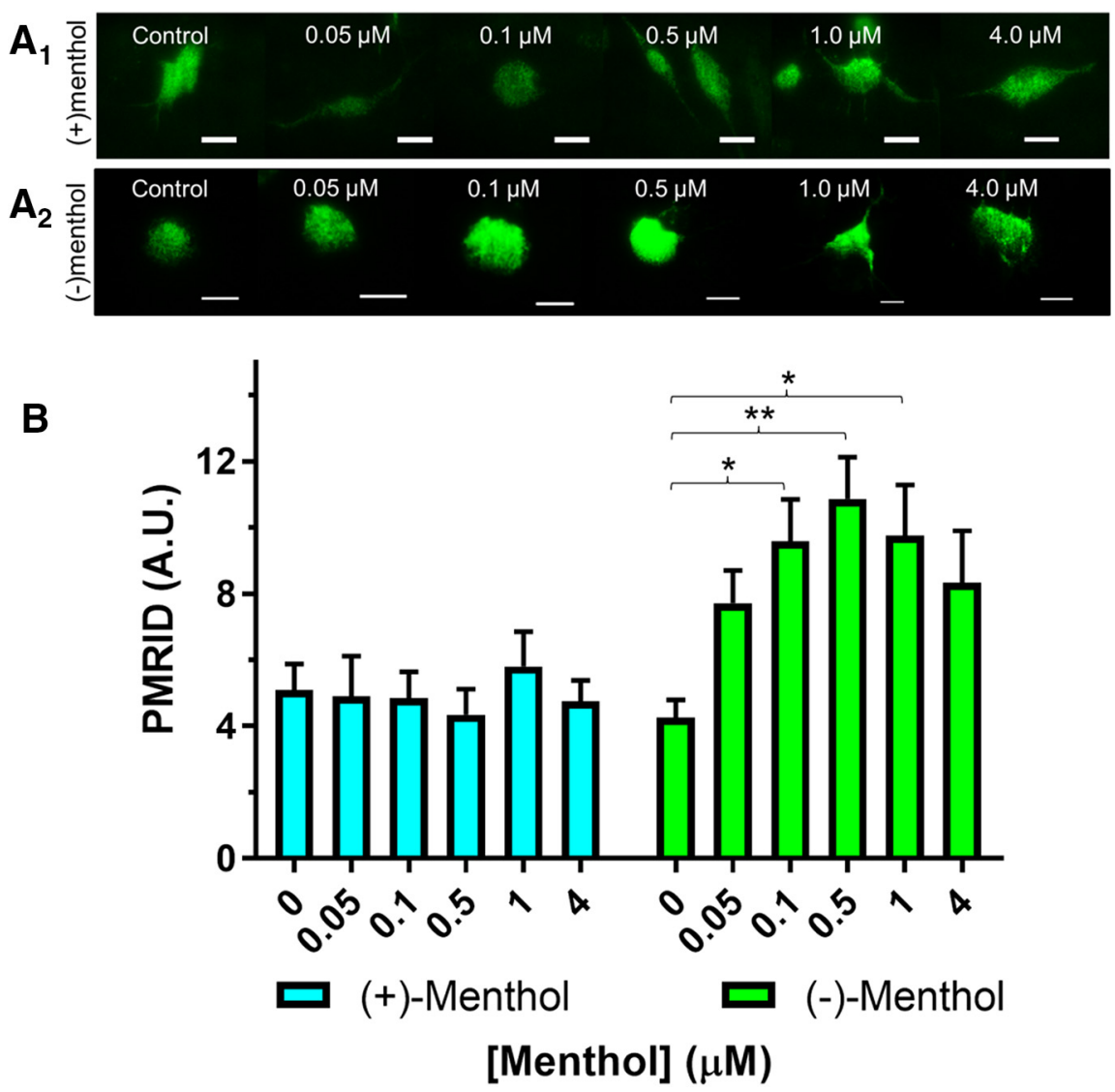

Figure 1. Chronic exposure of menthol stereoisomers causes different effects on $\alpha 4 \beta 2 \mathrm{nAChR}$ upregulation. $\boldsymbol{A}$, Representative TIRFM images of neuro-2a cells transfected with $\alpha 4$-SEP and $\beta 2 \mathrm{nAChR}$ subunits. Menthol stereoisomers (500 nM) were added $24 \mathrm{~h}$ before imaging sessions. Scale bars, $10 \mu \mathrm{m}$. Each panel image shows representative cells at pH 7.4. B, PMRID was quantified for SEP $\mathrm{nAChRs}$ following treatment with menthol stereoisomers. For each condition, $n>30$ cells. Data are the mean $\pm \mathrm{SEM}$. $* p<0.05$; $* * p<0.01$ (one-way ANOVA with Tukey). Two-way ANOVA, (+)-menthol vs (-)-menthol, $F_{(1,381)}=30.34$ and $p<0.0001$. Exact $p$ values are provided in the text.

determine how (+)-menthol and (-)-menthol may act differently to upregulate nAChRs transiently transfected into neuro-2a cells (Fig. 1). This combination of TIRFM and SEP-labeled nAChRs has been used previously to study the upregulation of nAChRs (Srinivasan et al., 2011; Henderson et al., 2014, 2016, 2017). A concentration range of $(+)$-menthol and (-)-menthol (0.05-4 $\mu \mathrm{M})$ was used to treat neuro-2a cells transiently transfected with $\alpha 4$-SEP and $\beta 2 \mathrm{nAChR}$ subunits for $24 \mathrm{~h}$ before imaging sessions. The upregulation of $\alpha 4 \beta 2$ nAChRs was examined by quantifying changes in the plasma membrane raw integrated density (PMRID), which indicates a change in the number of receptors that reside on the PM. With all concentrations, (+)-menthol neither increased nor decreased the PMRID of $\alpha 4$-SEP $\beta 2$ nAChRs (Fig. 1). (-)-Menthol produced a significant increase in $\alpha 4-\mathrm{SEP} \beta 2 \mathrm{nAChR}$ PMRID at concentrations of $0.1,0.5$, and $1 \mu \mathrm{M}$ when compared with control (Fig. 1; $p=0.03$, one-way ANOVA with post hoc Tukey's test). The effect of $(+)$-menthol and $(-)$-menthol on $\alpha 4 \beta 2$ nAChR PMRID was significant by two-way ANOVA $\left(F_{(1,381)}=30.3, p=0.0001\right)$. These results suggest that the previous effects we observed with (土)-menthol (Henderson et al., 2016, 2017) may be primarily mediated by $(-)$-menthol, and not $(+)$-menthol.

\section{Long-term treatment with menthol stereoisomers causes different effects on dopamine neuron firing frequency}

We previously used whole-cell patch-clamp electrophysiology to report that long-term treatment of $( \pm)$ menthol decreases the baseline firing of midbrain dopamine neurons in both mouse brain slices and cultured mouse midbrain neurons (Henderson et al., 2016). To further characterize different effects of menthol stereoisomers, we conducted similar studies with cultured mouse midbrain dopamine neurons treated for $10 \mathrm{~d}$ with (+)-menthol or (-)-menthol (500 nм; Figs. 2, 3). To facilitate the identification of midbrain dopamine neurons, we cultured neurons from TH-eGFP mice (Fig. 2A1-B3; Srinivasan et al., 2016; Henderson et al., 2017). The presence of hyperpolarization-activated inwardly rectifying nonspecific cation current $\left(I_{h}\right)$ and spike duration was also assessed to aid in the identification of dopamine neurons. For all TH-eGFP-positive neurons (Fig. 2A1-A3), we detected the presence of $I_{\mathrm{h}}$ and spike durations $>4 \mathrm{~ms}$.

We examined cultured dopamine neurons for changes in baseline firing frequency following $10 \mathrm{~d}$ of treatment with either $500 \mathrm{~nm}(+)$-menthol or $500 \mathrm{~nm}(-)$-menthol (Fig. $2 C, D)$. Control neurons exhibited a mean firing frequency 

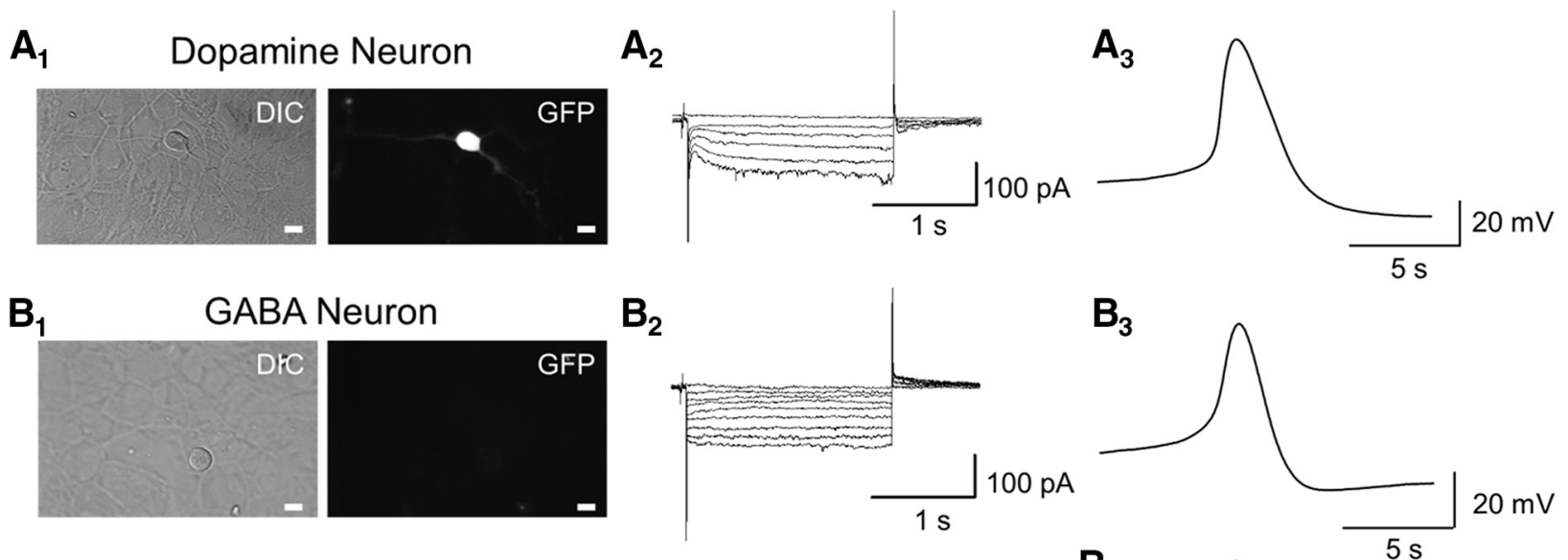
$20 \mathrm{mV}$

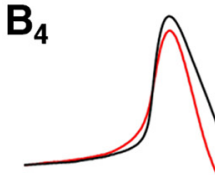

Dopamine Neuron GABA Neuron

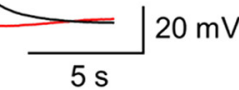

(+)-Menthol Treated DA Neuron
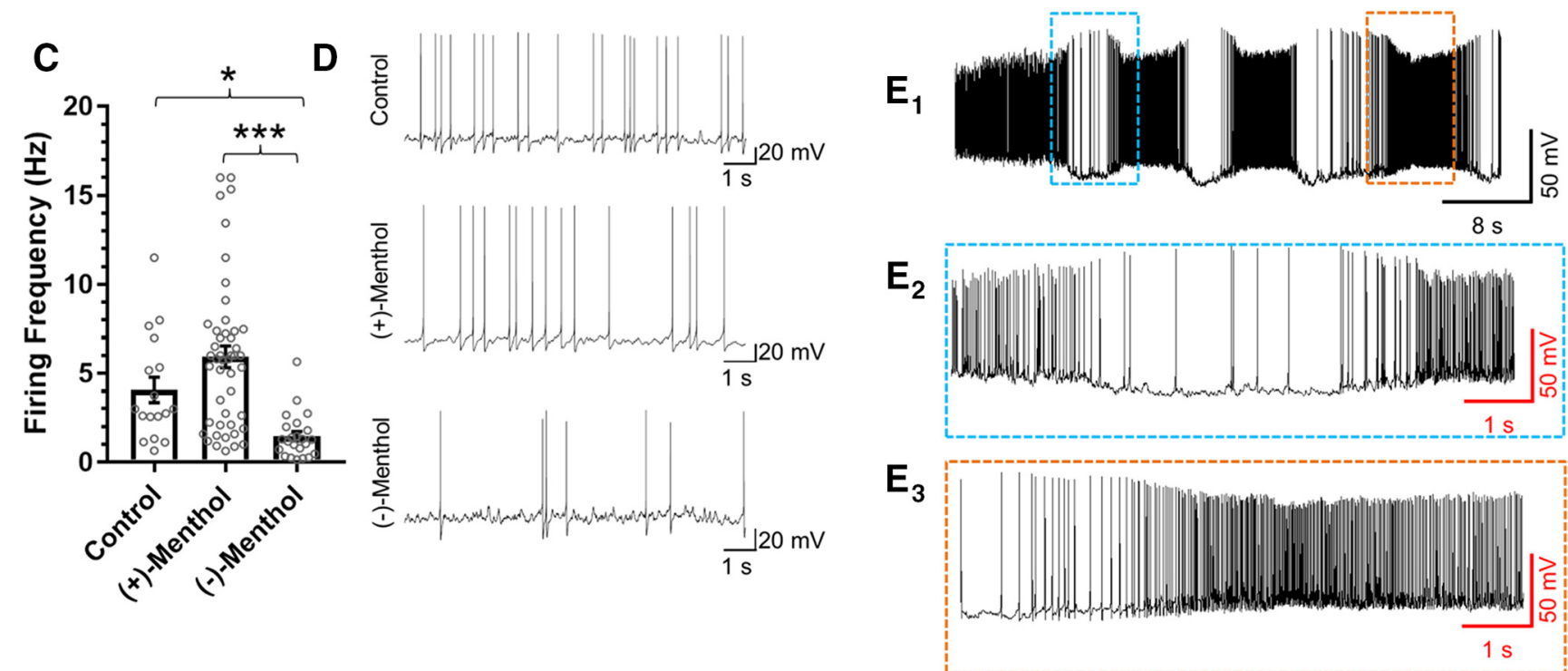

Figure 2. Menthol stereoisomers cause different effects on dopamine neuron baseline firing frequency. $\boldsymbol{A}_{1}, \boldsymbol{B}_{1}$, Representative image of a TH-positive cultured midbrain dopamine neuron $\left(\boldsymbol{A}_{1}\right)$ and a TH-negative putative GABA neuron $\left(\boldsymbol{B}_{1}\right)$. Scale bars, $20 \mu \mathrm{m}$. $\boldsymbol{A}_{\mathbf{2}}, \boldsymbol{B}_{\mathbf{2}}$, Representative waveforms of a TH-positive dopamine neuron with $I_{\mathrm{h}}\left(\boldsymbol{A}_{2}\right)$ and a TH-negative putative GABA neuron without $I_{\mathrm{h}}\left(\boldsymbol{B}_{2}\right)$. $\boldsymbol{A}_{3}$, $\boldsymbol{B}_{\mathbf{3}}, \boldsymbol{B}_{\mathbf{4}}$, Representative action potential from cultured dopamine and GABA neurons. $\boldsymbol{C}$, Baseline firing frequency of TH-positive dopamine neurons treated with control, (+)-menthol, or $(-)$-menthol (500 nM, each) for $10 \mathrm{~d}$. Data are the mean \pm SEM. $* p<0.05$; $* * p<0.01$ (one way ANOVA with Tukey). Circles overlaid with bars represent individual recordings that constitute the mean value for each respective group ( $n=17,44$, and 19 for control, (+)-menthol, and (-)-menthol, respectively). Exact $p$ values are provided in the text. Full data are plotted as a scatterplot with mean \pm SEM values plotted as an overlaid bar chart. $\boldsymbol{D}$, Representative whole-cell current-clamp traces for TH-positive dopamine neurons treated with control or menthol stereoisomers. $\boldsymbol{E}_{1}-\boldsymbol{E}_{3}, 9 \%$ of the $(+)$-mentholtreated dopamine neurons displayed dramatic variances in firing frequency. $\boldsymbol{E}_{2}$ and $\boldsymbol{E}_{3}$ are magnifications of blue and orange boxes, respectively, in $\boldsymbol{E}_{\mathbf{1}}$.

of $4.0 \pm 0.7 \mathrm{~Hz}$ (Fig. 2C). Long-term treatment with (-)menthol produced a significant decrease in dopamine neuron mean firing frequency to $1.5 \pm 0.3 \mathrm{~Hz}(p=0.04$, one-way ANOVA with Tukey's test). This change in firing frequency is similar to the effect we reported following long-term treatment with $( \pm)$-menthol (Henderson et al., 2016). Long-term treatment with (+)-menthol did not produce a significant change in dopamine neuron firing frequency (Fig. $2 C, D$ ). We did observe that $20 \%$ of neurons treated with $(+)$-menthol exhibited an increase in firing 
$A_{1}$

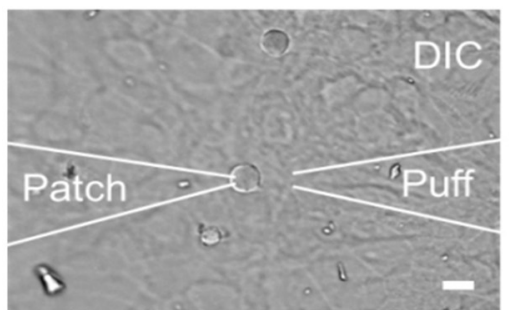

$A_{2}$

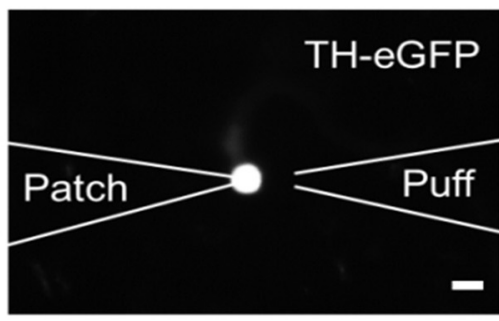

$B_{1}$

$\downarrow$ ACh Puff

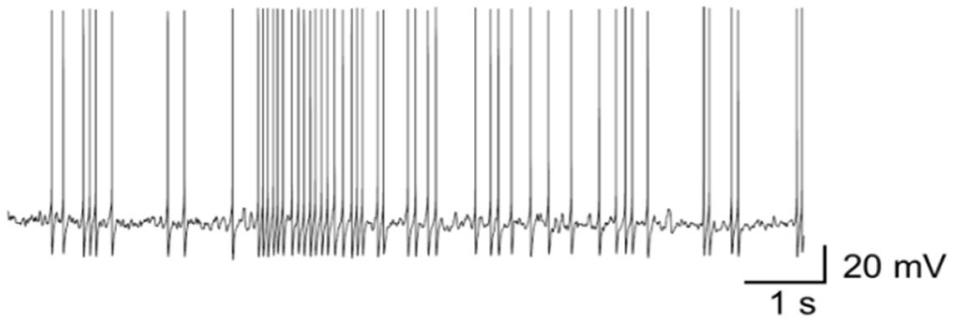

$\mathrm{B}_{2}$

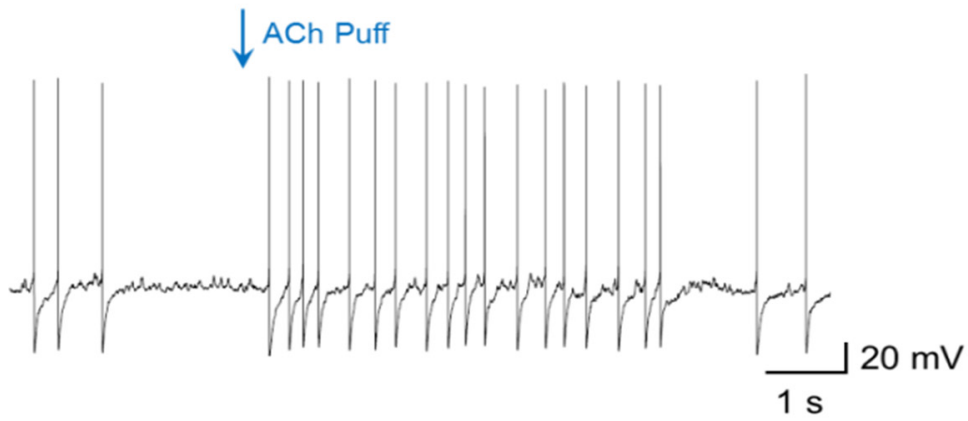

$\mathrm{B}_{3}$

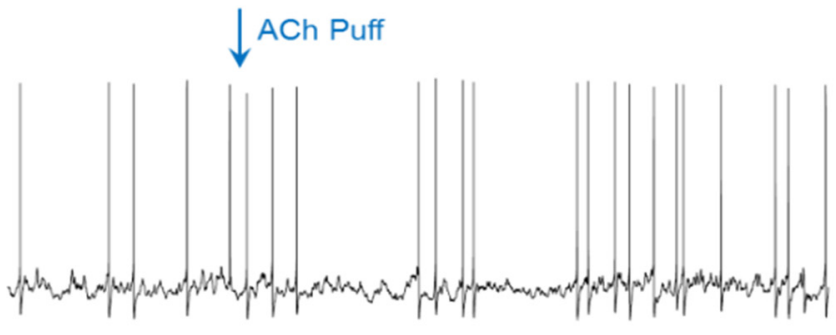

$20 \mathrm{mV}$
$\mathrm{C}_{1}$

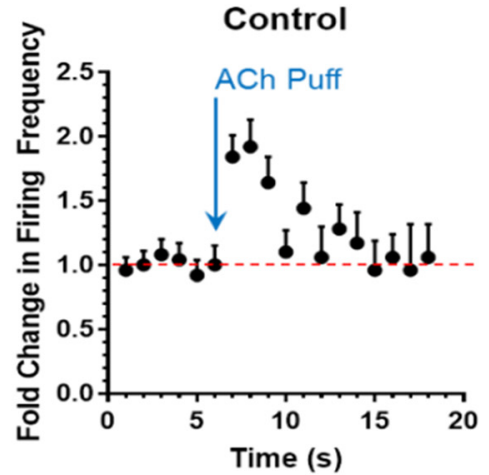

$\mathrm{C}_{2}$

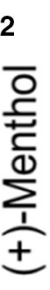

$\mathrm{C}_{3}$
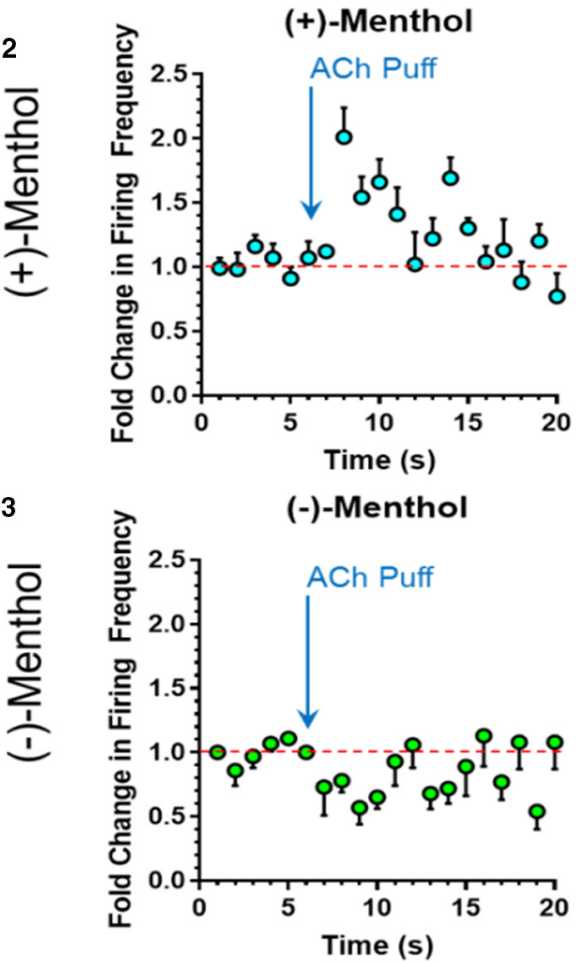

$\mathrm{C}_{4}$

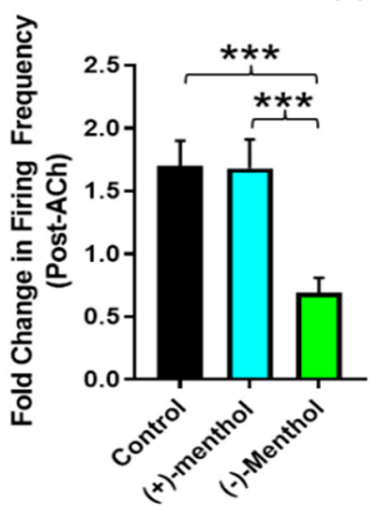

Figure 3. Chronic treatment with menthol stereoisomers causes different effects on dopamine neuron excitability. $\boldsymbol{A}_{\mathbf{1}}, \boldsymbol{A}_{\mathbf{2}}$, Representative image of TH-positive dopamine neuron with a diagram of the typical placement of patch and puffer pipets. $\boldsymbol{B}_{1}-\boldsymbol{B}_{3}$, Representative whole-cell current-clamp recordings from TH-positive dopamine neurons treated with control, $(+)$-menthol, or (-)-menthol (500 nм each) for $10 \mathrm{~d}$. Arrows indicate a $300 \mathrm{~ms}$ application of $300 \mu \mathrm{m}$ ACh to stimulate nAChRs. $\boldsymbol{C}_{1}-\boldsymbol{C}_{3}, \mathbf{M e a n}_{\text {firing }}$ frequency over time plot of TH-positive dopamine neurons before and after the ACh puff (indicated by arrow). $\boldsymbol{C}_{4}$, Quantification of firing frequency of dopamine neurons for the $3 \mathrm{~s}$ after ACh puff. Data are the mean \pm SEM. $n=5-9$ TH-positive dopamine neurons. 
A $\quad(\alpha 4)_{2}(\beta 2)_{3}$ vs. $(\alpha 4)_{2}(\beta 2)_{3}$

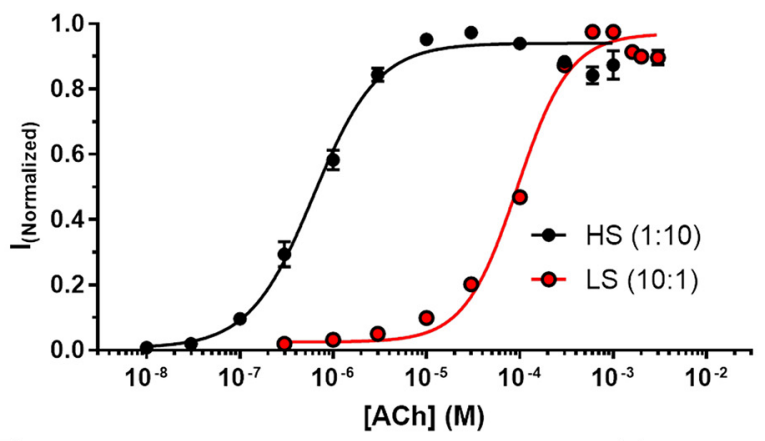

B

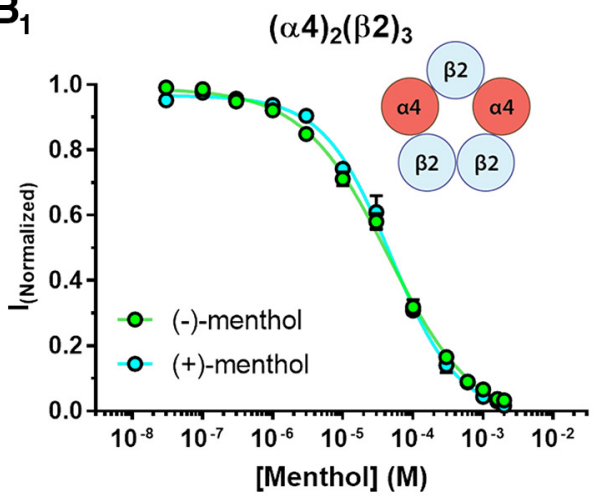

$C_{1}$

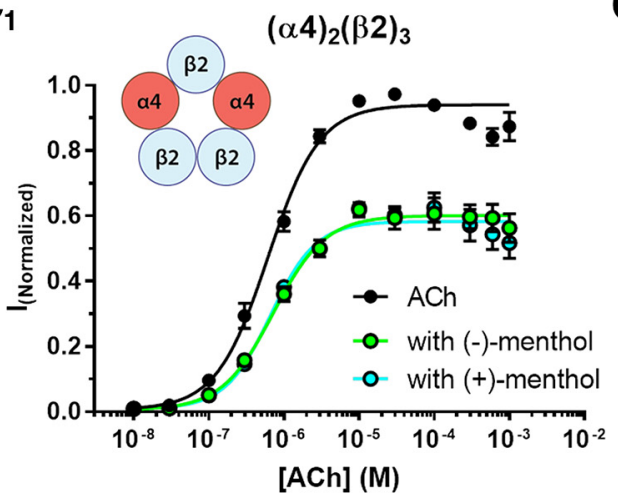

$\mathrm{B}_{2}$

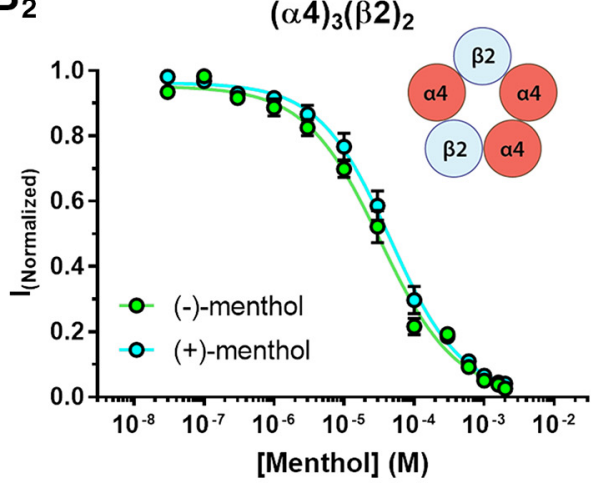

$\mathrm{C}_{2}$

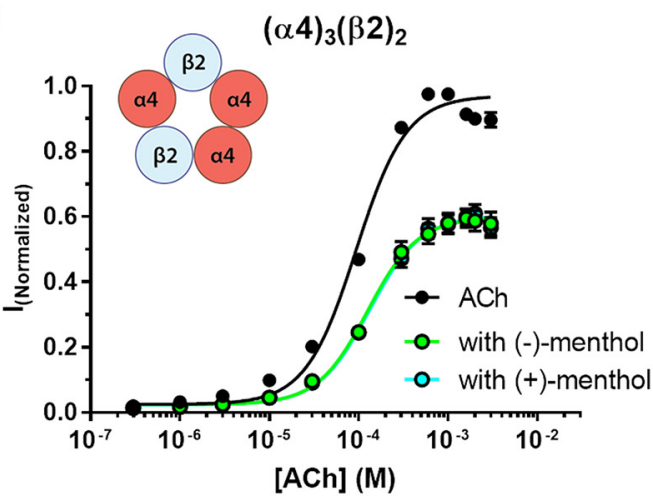

Figure 4. Acute applications display only slight pharmacological differences among menthol stereoisomers. A, Concentrationresponse curves of ACh on oocytes injected with $\alpha 4$ and $\beta 2 \mathrm{nAChR}$ subunits. Injections were biased to assemble high-sensitivity $(\alpha 4)_{2}(\beta 2)_{3}$ nAChRs $(1: 10)$ or low-sensitivity $(\alpha 4)_{3}(\beta 2)_{2}$ nAChRs $(10: 1) . \boldsymbol{B}_{1}, \boldsymbol{B}_{2}$, Concentration-response curve of menthol stereoisomers with high sensitivity $(\alpha 4)_{2}(\beta 2)_{3}$ nAChRs $\left(\boldsymbol{B}_{\boldsymbol{1}}\right)$ or low sensitivity $(\alpha 4)_{3}(\beta 2)_{2}$ nAChRs $\left(\boldsymbol{B}_{2}\right) . \boldsymbol{C}_{\boldsymbol{1}}, \boldsymbol{C}_{\boldsymbol{2}}$, Concentration-response curve of ACh in the absence or presence of $(-)$-menthol or $(+)$-menthol $(50 \mu \mathrm{M})$ with high sensitivity $(\alpha 4)_{2}(\beta 2)_{3} \mathrm{nAChRs}\left(\boldsymbol{C}_{1}\right)$ or low sensitivity $(\alpha 4)_{3}(\beta 2)_{2}$ nAChRs $\left(\boldsymbol{C}_{2}\right)$. Refer to Tables 1-3 for values for Hill coefficient, $\mathrm{EC}_{50}$, and $\mathrm{IC}_{50}$.

frequency. All neurons exhibiting an increase in firing frequency were positive for TH-eGFP fluorescence, $I_{\mathrm{h}}$, and spike duration $>4 \mathrm{~ms}$. Therefore, we are confident that these neurons are indeed dopamine neurons and not GABA neurons, which are also present in these cultured

Table 1: Concentration-response relationships of $\mathrm{ACh}$ on $(\alpha 4)_{3}(\beta 2)_{2}$ and $(\alpha 4)_{2}(\beta 2)_{3}$ nAChRs

\begin{tabular}{lllll}
\hline & $\mathrm{n}_{\mathrm{H}}$ & $\mathrm{EC}_{50}(\mu \mathrm{M})$ & $n$ & $\mathrm{I}_{\max }(\mu \mathrm{A})$ \\
$1: 10(\alpha 4)_{2}(\beta 2)_{3}$ & $1.54 \pm 0.08$ & $93.4 \pm 3.34$ & 10 & $0.3-1.1$ \\
$10: 1(\alpha 4)_{3}(\beta 2)_{2}$ & $1.27 \pm 0.10$ & $0.62 \pm 0.04$ & 15 & $0.2-13.6$
\end{tabular}

midbrain neuron preparations. Further examination showed that a few of these neurons (10\% of the $20 \%)$ exhibited spontaneous variations in baseline firing frequency (Fig. 2E1-E3).

\section{Long-term treatment with menthol stereoisomers causes different effects on dopamine neuron excitability}

We previously reported that ( \pm )-menthol alters dopamine neuron excitability (Henderson et al., 2016). Dopamine neurons exhibit increases in firing frequency when exposed to a nAChR agonist (Nashmi et al., 2007; Drenan 
Table 2 : Concentration-response relationships of menthol stereoisomers on $(\alpha 4)_{3}(\beta 2)_{2}$ and $(\alpha 4)_{2}(\beta 2)_{3}$ nAChRs

\begin{tabular}{|c|c|c|c|c|}
\hline & $\mathrm{n}_{\mathrm{H}}$ & $\mathrm{IC}_{50}(\mu \mathrm{M})$ & $n$ & $I_{\max }(\mu \mathrm{A})$ \\
\hline \multicolumn{5}{|l|}{$1: 10(\alpha 4)_{2}(\beta 2)_{3}^{a}$} \\
\hline (-)-Menthol & $-0.71 \pm 0.02$ & $44.9 \pm 1.62$ & 10 & $0.08-1.34$ \\
\hline (+)-Menthol & $-0.90 \pm 0.03$ & $48.3 \pm 1.67^{c}$ & 10 & $0.12-0.97$ \\
\hline \multicolumn{5}{|l|}{$10: 1(\alpha 4)_{3}(\beta 2)_{2}^{b}$} \\
\hline (-)-Menthol & $-0.81 \pm 0.03$ & $33.1 \pm 1.83$ & 10 & $0.09-1.30$ \\
\hline (+)-Menthol & $-0.85 \pm 0.03$ & $45.5 \pm 2.03^{d}$ & 10 & $0.13-1.37$ \\
\hline
\end{tabular}

a Stimulated with $2 \mu \mathrm{M}$ ACh.

b Stimulated with $100 \mu \mathrm{M}$ ACh.

${ }^{c} p=0.033, I_{50}$ of $(-)$-menthol vs. (+)-menthol on $(\alpha 4)_{2}(\beta 2)_{3}$ nAChRs.

${ }^{d} p=0.0001, I_{50}$ of $(-)$-menthol vs. (+)-menthol on $(\alpha 4)_{2}(\beta 2)_{3} \mathrm{nAChRs}$

et al., 2008). When menthol is combined with nicotine, it can potentiate this effect (Henderson et al., 2017). Despite this, long-term treatment with menthol alone decreased dopamine neuron excitability (Henderson et al., 2016). Using similar methods, we investigated both menthol stereoisomers for their ability to alter dopamine neuron excitability. Similar to the previous experiments, we used TH-eGFP midbrain cultures and treated them for $10 \mathrm{~d}$ with (+)-menthol or (-)-menthol (both at $500 \mathrm{~nm}$ ). We recorded dopamine neurons in current-clamp mode and applied a $300 \mathrm{~ms}$ puff of $300 \mu \mathrm{M}$ ACh to stimulate nAChRs (Fig. 3). A concentration of $300 \mu \mathrm{M}$ ACh was selected to stimulate a peak response from the nAChRs residing on DA neurons. Control dopamine neurons exhibited a transient, twofold ACh-induced increase in firing frequency that was similar to previous reports (Henderson et al., 2016; Fig. $3 B 1, C 1)$. Dopamine neurons exposed to $(+)$-menthol exhibited a similar 1.9-fold transient ACh-induced increase in firing frequency (Fig. 3B2,C2). In contrast, dopamine neurons treated with (-)-menthol exhibited a consistent ACh-induced decrease in firing frequency (Fig. 3B3,C3,C4). When we compared the fold change in firing frequency following ACh application, we observed a significant effect of treatment with menthol stereoisomers (one-way ANOVA, $\left.F_{(2,17)}=9.96, p=0.0014\right)$. The change in dopamine neuron firing frequency following long-term treatment with (-)-menthol was significant when compared with both control-treated and (+)-menthol-treated dopamine neurons ( $p=0.002$ and $p=0.007$, respectively). These data further support the suggestion that (-)menthol is the primary mediator for the effects we previously observed with ( \pm )-menthol.

\section{Acute applications of menthol stereoisomers exhibit similar pharmacologic profiles}

Our long-term applications of menthol have studied submicromolar concentrations that we perceive to be pharmacologically relevant (Henderson et al., 2016). Pioneering observations showed that menthol at higher concentrations (100- to 1000-fold greater than the concentration we use in our long-term studies) acts as a negative allosteric modulator of $\alpha 4 \beta 2$ nAChRs (Hans et al., 2012), a noncompetitive antagonist of $\alpha 3 \beta 4$ nAChRs (Ton et al., 2015), and a noncompetitive antagonist of $\alpha 7$ nAChRs (Ashoor et al., 2013b). Although the concentrations used in these studies may not be pharmacologically relevant in some cases, this profile suggests that menthol directly interacts with nAChRs and most likely at an allosteric site. Using $X$. laevis oocytes and two-electrode voltage-clamp electrophysiology, we used concentration-response assays to examine how acute applications of $(+)$-menthol and (-)-menthol differed in their ability to act as inhibitors of $\alpha 4 \beta 2 \mathrm{nAChR}$ function (Fig. 4).

Long-term treatment with $\mathrm{nAChR}$ ligands can change the stoichiometry of $\alpha 4 \beta 2$ nAChRs. Thus, we studied menthol inhibition on both the low-sensitivity and highsensitivity stoichiometries of $\alpha 4 \beta 2 \mathrm{nAChRs}\left[(\alpha 4)_{3}(\beta 2)_{2}\right.$ and $(\alpha 4)_{2}(\beta 2)_{3}$, respectively; Fig. 4]. On both $\alpha 4 \beta 2$ nAChR stoichiometries, we observed potencies and efficacies for ACh that are similar to previously reported data (Fig. $4 A$, Table 1; Nelson et al., 2003; Tapia et al., 2007). Both $(+)$-menthol and (-)-menthol inhibited both stoichiometries of $\alpha 4 \beta 2$ nAChRs (Fig. 4B1,B2, Table 2). (-)-Menthol was modestly more potent at both stoichiometries $(p=$ 0.033 and $p=0.0001$ for $(\alpha 4)_{2}(\beta 2)_{3}$ and $(\alpha 4)_{3}(\beta 2)_{2}$

Table 3: Concentration-response of ACh in the absence and presence of menthol stereoisomers on $(\alpha 4)_{3}(\beta 2)_{2}$ and $(\alpha 4)_{2}(\beta 2)_{3}$ nAChRs

\begin{tabular}{|c|c|c|c|c|}
\hline \multicolumn{5}{|l|}{$\begin{array}{l}\text { Receptor } \\
1: 10(\alpha 4)_{2}(\beta 2)_{3}{ }^{a}\end{array}$} \\
\hline With (-)-menthol & $1.38 \pm 0.08$ & $0.66 \pm 0.0318$ & 12 & $0.05-0.82$ \\
\hline \multicolumn{5}{|l|}{$10: 1(\alpha 4)_{3}(\beta 2)_{2}^{b}$} \\
\hline ACh only & $1.74 \pm 0.07$ & $99.8 \pm 2.37$ & 19 & $0.2-13.6$ \\
\hline With (-)-menthol & $1.58 \pm 0.04$ & $120.8 \pm 2.37$ & 18 & $0.1-9.9$ \\
\hline
\end{tabular}

\footnotetext{
a Stimulated with $2 \mu \mathrm{M}$ ACh.
}

b Stimulated with $100 \mu \mathrm{m}$ ACh. 


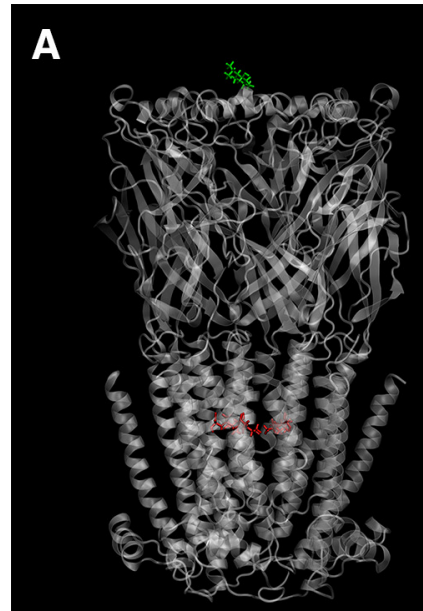

B

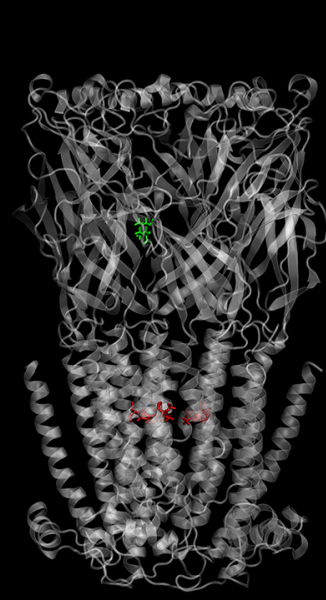

E

D

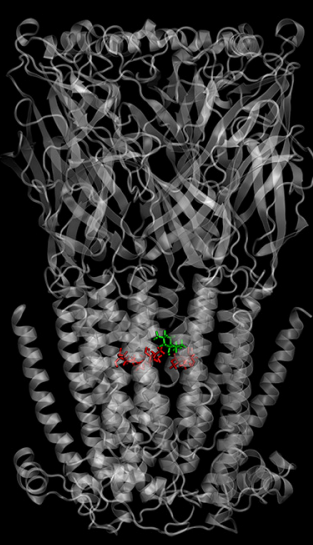

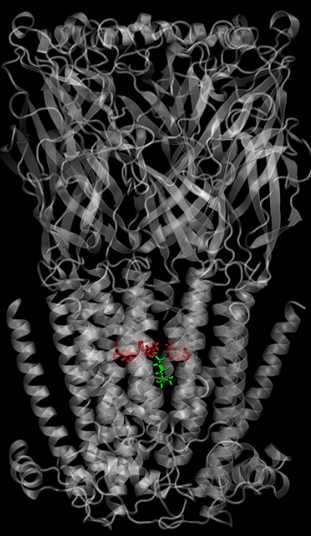

C

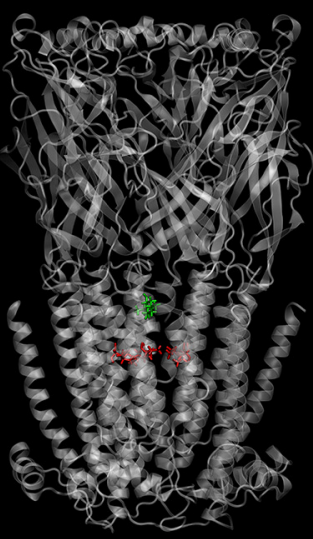

$\mathbf{F}$

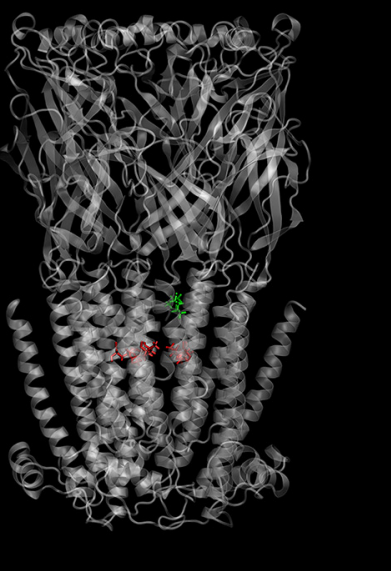

Movie 1. We show six still frames from the movie of a menthol molecule during a flooding simulation. $\boldsymbol{A}$, Menthol (shown in green sticks) is introduced in the extracellular solution. Menthol first encounters the extracellular domain (ECD) of the human $\alpha 4 \beta 2$ nicotinic receptor. $\boldsymbol{B}$, Menthol binds to different residues on the ECD. $\boldsymbol{C}$, Menthol reaches the "top" of the M2 region. $\boldsymbol{D}-\boldsymbol{F}$, For the rest of the flooding simulation, menthol remains in the transmembrane domain, between the "top" of the M2 region and the ring of 9' Leu residues (shown as red sticks). Menthol does not move toward the cytoplasmic end of M2. [View online]

nAChRs, respectively; Table 2). We also compared (+)menthol and (-)-menthol with regard to competitive versus noncompetitive actions. Using methods similar to those of Hans et al. (2012), we used a concentration

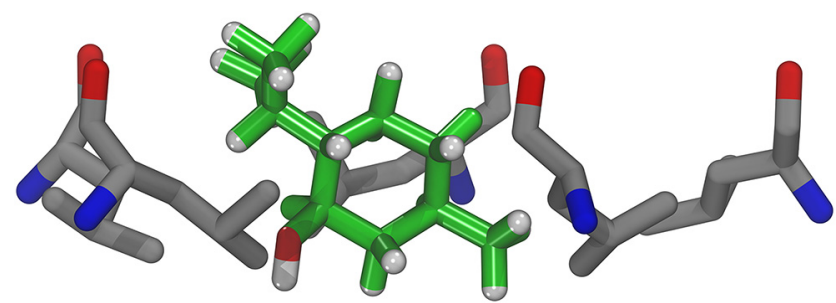

Movie 2. We present a higher-resolution version of a still frame from the movie, showing a menthol molecule sitting in the center of the ring of $9^{\prime}$ leucine residues. The carbons of menthol are shown in green, its hydrogens in white, and its oxygen in red. The carbons of the 9' leucine residues are shown in gray, their oxygens in red, and their nitrogens in blue. The hydrogens of the leucine residue are not shown in the figure. [View online] response of $\mathrm{ACh}$ in the absence and presence of menthol stereoisomers $(50 \mu \mathrm{M})$ to test whether menthol caused insurmountable inhibition (a type of noncompetitive inhibition) or a parallel shift to the right in $\mathrm{EC}_{50}$ (indicative of competitive inhibition; Fig. 4C1,C2). Here both (+)menthol and (-)-menthol caused a $40 \%$ decrease in the

Table 4 : IC ${ }_{40}$ values for (-)-menthol on $\left(\alpha 4\left[\mathrm{~L} \mathbf{X}^{\prime} \mathrm{X}\right)_{2}(\beta 2)_{3}\right.$ mutant nAChRs

\begin{tabular}{lll}
\hline Residue & $\mathrm{IC}_{30}(\mu \mathrm{M}(+)$-menthol \pm SEM $)$ & $n$ \\
Ala & $855 \pm 130$ & 18 \\
Ser & $357 \pm 62.0$ & 11 \\
Gln & $117 \pm 14.0$ & 13 \\
Thr & $547 \pm 110$ & 11 \\
Cys & $162 \pm 23.0$ & 11 \\
Ile & $50.1 \pm 11.0$ & 7 \\
Met & $18.4 \pm 1.60$ & 10 \\
Leu (WT $)$ & $35.6 \pm 5.70$ & 9 \\
Phe & $121 \pm 10.0$ & 10 \\
Trp & $26.6 \pm 4.90$ & 10 \\
\end{tabular}


Table 5 : IC ${ }_{30}$ values for $(+)$-menthol on $\left(\alpha 4[\text { L9X] })_{2}(\beta 2)_{3}\right.$ mutant nAChRs

\begin{tabular}{lll}
\hline Residue & $\mathrm{IC}_{30}(\mu \mathrm{m}(+)$-menthol \pm SEM) & $n$ \\
Ala & $760 \pm 100$ & 9 \\
Ser & $215 \pm 41.0$ & 11 \\
Gln & $114 \pm 12.0$ & 10 \\
Thr & $475 \pm 47.0$ & 9 \\
Cys & $108 \pm 28.0$ & 11 \\
Ile & $70.4 \pm 18.0$ & 9 \\
Met & $15.6 \pm 5.50$ & 15 \\
Leu (WT) & $27.1 \pm 4.50$ & 8 \\
Phe & $60.0 \pm 12.0$ & 8 \\
Trp & $11.3 \pm 1.60$ & 18 \\
& & \\
\hline
\end{tabular}

efficacy of ACh with no significant change in $E_{50}$ (Table 3, Fig. 4C1,C2). From this, both menthol stereoisomers act as noncompetitive inhibitors of $\alpha 4 \beta 2$ nAChRs with similar potency despite the clear difference we observed with their long-term, low-dose applications.

\section{Flooding simulations suggest a putative menthol binding site on $\alpha 4 \beta 2$ nAChRs}

As computational resources become more efficient, more studies are using molecular dynamics to guide experimental design (Ashoor et al., 2013b; Dalton et al., 2014; Arcario et al., 2017; Bottaro and Lindorff-Larsen, 2018). We used "flooding" simulations in which copies of menthol were added to the solution phase of a simulation system containing an $\alpha 4 \beta 2$ nAChR (Brannigan et al., 2010). Most of the menthol molecules partition to the lipid membrane, leaving just a small percentage of the total number of menthol molecules in the aqueous phase. The protein remained stable throughout the simulation and predicted binding sites were deemed notable if menthol remained within $5 \AA$ of the protein for $>50 \mathrm{~ns}$. Many of these predicted binding sites were on the periphery of the protein; however, one was inside the receptor pore (Movie 1.). Specifically, the site in the pore was the ring of leucines at the 9' position on TM2 (Movie 2.). This position is important for modulating the sensitivity of the protein to agonists without affecting the agonist-binding site (Labarca et al., 1995; Kearney et al., 1996; Kosolapov et al., 2000). Based on the simulation and the importance of the $9^{\prime}$ site, we probed this prediction further with oocyte expression experiments (Tables 4, 5). We also probed many of the other predicted binding sites on the periphery of the protein, but our results showed that mutating these sites had no meaningful influence on menthol potency (Tables 6,7$)$. Among these mutants, we observed no detectable currents from $(\alpha 4[\mathrm{E} 182 \mathrm{~A}])_{3}(\beta 2[\mathrm{wt}])_{2},(\alpha 4[\mathrm{D} 51 \mathrm{~A}$, $\mathrm{E} 52 \mathrm{~A}])_{3}(\beta 2[\mathrm{wt}])_{2},(\alpha 4[\mathrm{Q} 55 \mathrm{~A}])_{3}(\beta 2[\mathrm{wt}])_{2},\left(\alpha 4[[280 \mathrm{~A}])_{3}(\beta 2[\mathrm{wt}])_{2},(\alpha 4\right.$ $[\mathrm{l226A}])_{3}(\beta 2[\mathrm{wt}])_{2}, \quad(\alpha 4[\mathrm{~L} 279 \mathrm{~A}])_{3}(\beta 2[\mathrm{wt}])_{2}, \quad(\alpha 4[\mathrm{Y} 283 \mathrm{~A}])_{3}(\beta 2[\mathrm{wt}])_{2}$, $(\alpha 4[\mathrm{~L} 229 \mathrm{~A}])_{3}(\beta 2[\mathrm{wt}])_{2}, \quad(\alpha 4[\mathrm{G} 281 \mathrm{~W}])_{3}(\beta 2[\mathrm{wt}])_{2}, \quad(\alpha 4[\mathrm{E} 282 \mathrm{D}])_{3}$ $(\beta 2[w t])_{2},(\alpha 4[E 282 A])_{3}(\beta 2[w t])_{2}$, and $(\alpha 4[w t])_{3}(\beta 2[\mid 214 A])_{2}$ when $1 \mathrm{~mm}$ ACh was applied. Additionally, $\mathrm{IC}_{50}$ data were not trustworthy for (-)-menthol for $(\alpha 4[\mathrm{wt}])_{3} \quad(\beta 2[\mathrm{G} 364 \mathrm{~L}])_{2}, \quad(\alpha 4[\mathrm{wt}])_{3}$ $(\beta 2[\mathrm{~F} 306 \mathrm{~W}])_{2},(\alpha 4[\mathrm{M} 288 \mathrm{~W}])_{3}(\beta 2[\mathrm{wt}])_{2},(\alpha 4[\mathrm{wt}])_{3}(\beta 2[\mathrm{M} 280 \mathrm{~W}])_{2}$, and $\left(\alpha 4[\mathrm{~V} 356 \mathrm{~W})_{3}(\beta 2[\mathrm{M} 368 \mathrm{~W}])_{2}\right.$ because currents were too small for systematic measurements at approximately halfmaximal $[\mathrm{ACh}]$. We did not calculate $\mathrm{IC}_{50}$ values for (-)- menthol for $\left(\alpha 4\left[\mathrm{Lg}^{\prime} \mathrm{A}\right]\right)_{3} \quad(\beta 2[\mathrm{M} 368 \mathrm{~W}])_{2}, \quad(\alpha 4[\mathrm{~L} 9 \mathrm{~T}])_{3} \quad(\beta 2[\mathrm{wt}])_{2}$, $\left.\left(\alpha 4\left[\mathrm{Lg}^{\prime} \mathrm{A}\right]\right)_{3}(\beta 2[\mathrm{wt}])_{2}, \alpha 4\left[\mathrm{LG}^{\prime} \mathrm{A}\right]\right)_{3}(\beta 2[\mathrm{~V} 360 \mathrm{~W}])_{2}$, and $\left(\alpha 4\left[\mathrm{Lg}^{\prime} \mathrm{A}\right]\right)_{3}$ $(\beta 2[\mathrm{~F} 328 \mathrm{~W}])_{2}$ because inhibition with $(-)$-menthol was too weak for systematic fitting to the Hill equation. We probed only a subset of residues with (+)-menthol for stereoselectivity comparison experiments.

\section{The L9' residue on M2 is important for menthol inhibition}

Based on the simulation results, we made additional mutations to $(\alpha 4)_{2}(\beta 2)_{3}$ nAChRs at the L9' site and measured dose-response relations for (-)-menthol using twoelectrode voltage-clamp electrophysiology (Fig. 5). The data confirmed that menthol block depends on the residue at the $9^{\prime}$ position on the M2 helix in nAChR subunits (Fig. 5). Further, mutating this position to different amino acids elicited a range of potency for menthol inhibition. The greatest effect on the ability of menthol to inhibit $\alpha 4 \beta 2 \mathrm{nAChRs}$ was observed with the leucine to alanine (L9'A) mutation (Fig. $5 A 1, A 2$, Tables 4,5$)$. The $\alpha 4\left[\mathrm{Lg}^{\prime} \mathrm{A}\right] \beta 2$ receptor is $\sim 100$-fold less sensitive to menthol block than wild type (WT; Fig. $5 B$ ). At the other extreme of sensitivity, $\alpha 4[$ [L9'M] $\beta 2$ is more sensitive ( $\sim 10$-fold). Based on these results, menthol-induced inhibition depends strongly on the side chain at the 9' position.

A possible complication is that we tested menthol using much lower ACh for measurements on the $\left(\alpha 4\left[\mathrm{Lg}^{\prime} \mathrm{A}\right]\right)_{3}(\beta 2)_{2}$ receptor than on the WT receptor. This choice was driven by our desire to test menthol effects at roughly equally effective [ACh] for each individual receptor combination; the $\left(\alpha 4[\text { L9'A })_{3}(\beta 2)_{2}\right.$ receptor has $10^{4}$-fold lower $\mathrm{EC}_{50}$ values for ACh when compared with the wild-type receptor (Labarca et al., 1995; Kearney et al., 1996; Kosolapov et al., 2000; Dash et al., 2014). Nonetheless, one asks whether one can treat the menthol block as truly independent of events of the agonist binding site. To address this issue, we performed additional experiments using $1 \mu \mathrm{M}$ ACh to activate the WT and mutant receptors (Fig. 5B). The partially activated WT receptor is blocked $\sim 50 \%$ by $\sim 30 \mu \mathrm{M}$ menthol; but the fully activated $\left(\alpha 4\left[\mathrm{Lg}^{\prime} \mathrm{A}\right]\right)_{3}(\beta 2)_{2}$ receptor remains almost completely unblocked by [menthol] $<1 \mathrm{~mm}$. The data therefore preserve the concept that menthol exerts a "noncompetitive" block (presumably at the 9' site in the transmembrane pore), and this block can be measured over a wide range of [ACh].

Next, we determined the minimum number of $9^{\prime}$ mutations, within an nAChR pentamer, required to perturb the activity of menthol. Because the L9'A mutation most drastically reduced menthol sensitivity, we varied the number of L9'A mutations within the receptor pentamer. Since nAChRs are pseudosymmetric with fivefold symmetry, we can make up to five 9'A mutations. We made mutants with one, two, and three $9^{\prime} \mathrm{A}$ mutations since $\left(\alpha 4\left[\mathrm{Lg} \mathrm{C}^{\prime} \mathrm{A}\right]\right)_{3}(\beta 2)_{2}$ proved to be unaffected by menthol (Fig. 6A). We were also interested in determining whether this was a subunit-dependent effect, so we incorporated 9'A mutations in either $\beta 2$ or $\alpha 5 \mathrm{nAChR}$ subunits. In all the mutants tested, as long as there was at least one 9'A mutation in $\alpha 4, \alpha 5$, or $\beta 2 \mathrm{nAChR}$ subunits, inhibition by $100 \mu \mathrm{M}(-)$-menthol was significantly reduced (unpaired $t$ test, $p=0.0001$; Fig. $6 A$ ). The reduction in the 
Table 6: $\mathrm{EC}_{50}$ values for mutant $\alpha 4 \beta 2 \mathrm{nAChRs}$

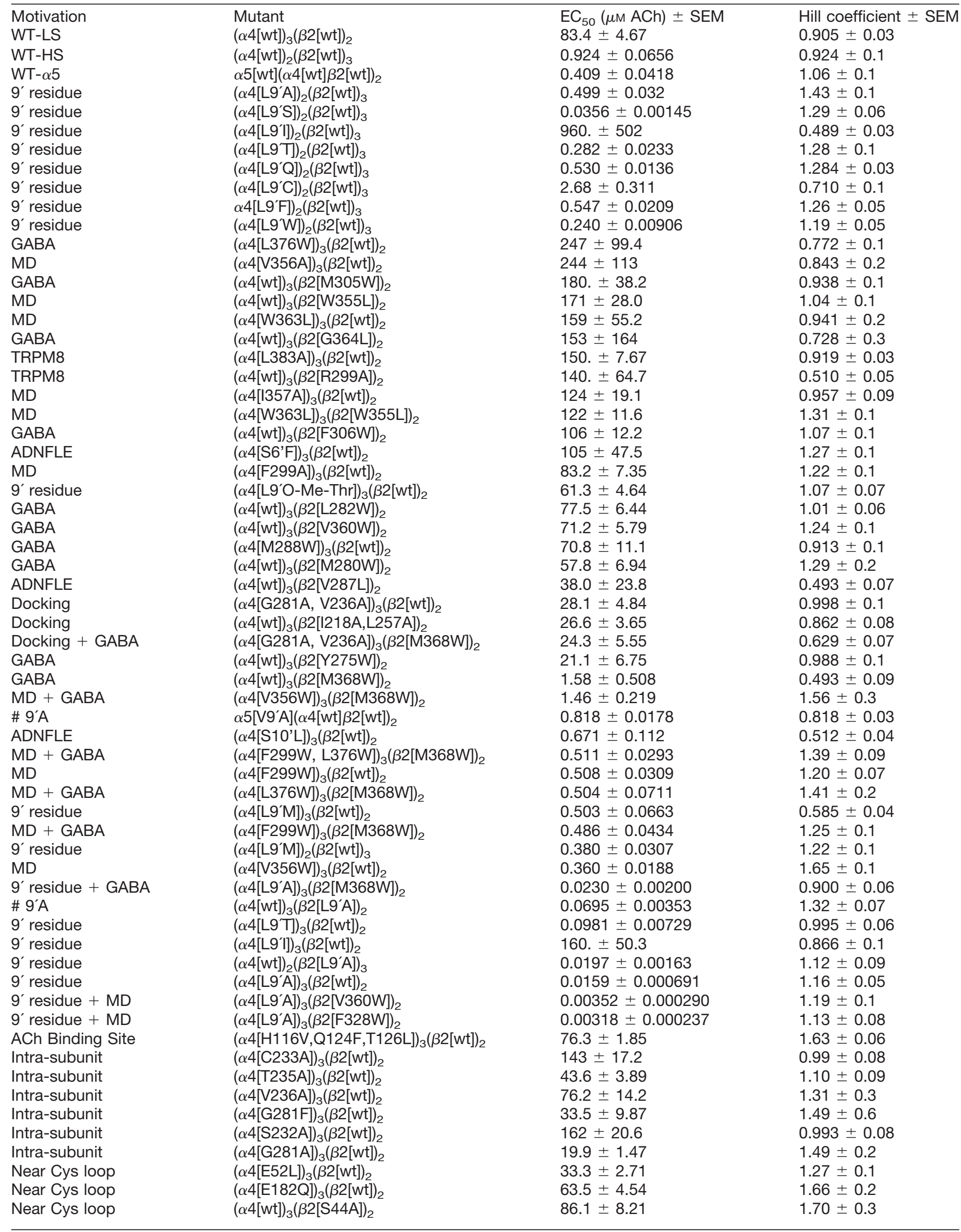




\begin{tabular}{llll}
\hline Motivation & Mutant & EC $_{50}(\mu \mathrm{M}$ ACh $) \pm$ SEM & Hill coefficient \pm SEM \\
$(\alpha 4[\mathrm{~L} 265 \mathrm{~A}])_{3}(\beta 2[\mathrm{wt}])_{2}$ & $26.5 \pm 6.58$ & $0.864 \pm 0.2$ & $1.31 \pm 0.4$ \\
Channel pore & $(\alpha 4[\mathrm{wt}])_{3}(\beta 2[\mathrm{~L} 257 \mathrm{~A}])_{2}$ & $0.316 \pm 0.101$ & $0.962 \pm 0.1$ \\
Interfacial & $(\alpha 4[\mathrm{~F} 286 \mathrm{~A}])_{3}(\beta 2[\mathrm{wt}])_{2}$ & $46.5 \pm 8.45$ & $1.21 \pm 0.1$ \\
Interfacial & $(\alpha 4[\mathrm{wt}])_{3}(\beta 2[\mathrm{I} 218 \mathrm{~A}])_{2}$ & $119 \pm 11.7$ & $0.868 \pm 0.5$
\end{tabular}

WT-LS, Wild-type $\alpha 4 \beta 2$ receptor with the low sensitivity stoichiometry; WT-HS, wild-type $\alpha 4 \beta 2$ receptor with the high sensitivity stoichiometry; WT- $\alpha 5$, wildtype $\alpha 4 \beta 2$ receptor with $\alpha 5$ in the auxiliary position; $9^{\prime}$ residue, a mutant at the $9^{\prime}$ position to probe the effects of mutations at this site; GABA, analogous site for the menthol binding site in the GABA receptor; MD, molecular dynamics predicted position; TRPM8, analogous site for the menthol binding site on the TRPM8 receptor; ANDFLE, a mutant that is found in ADNFLE patients; Docking, position predicted by preliminary docking studies; \#L9'A, mutant made to probe the effects that the number of 9'A mutations has on the effects of menthol; ACh binding site, the putative ACh binding site; Intra-subunit, site between subunits in the transmembrane domain of $\alpha 4 \beta 2$; Near Cys loop, site that is near the Cys loop of $\alpha 4 \beta 2$; Channel pore, site that is in the channel pore of $\alpha 4 \beta 2$; Interfacial, a site on the transmembrane domain of a single subunit that faces toward the other transmembrane domain helices on the same subunit.

ability of menthol to inhibit nAChRs that harbor 9'A mutations suggests that menthol binds to this site in TM2.

\section{One bound menthol molecule is sufficient for $\alpha 4 \beta 2$ inhibition}

Hill coefficients, which describe the overall steepness of the concentration-response relation, are often used to gain an understanding of ligand-receptor binding stoichiometry (Prinz, 2010). We investigated the minimum number of bound menthol molecules necessary for channel inhibition. To test this, we calculated the Hill coefficients for both stereoisomers of menthol on all of the mutants tested (Fig. 6B). Since the average Hill coefficient is not significantly different from unity for either (-)-menthol or $(+)$-menthol, we concluded that the presence of a single bound menthol molecule is sufficient for $\mathrm{nAChR}$ inhibition.

\section{The activity of (+)-menthol and (-)-menthol depends on the end-to-end length of the $9^{\prime}$ residue}

Which properties of the side chain at 9' are important for the inhibitory activity of menthol on $\alpha 4 \beta 2 \mathrm{nAChRs}$ ? We examined the $\mathrm{IC}_{40}$ or $\mathrm{IC}_{30}$ values for (-)-menthol and (+)-menthol, respectively, against the 9' residue volume, end-to-end length, and other parameters in the reduced amino acid index (AA index) (Fig. 7, Fig. 7-1, and Fig. 7-2; Zamyatnin, 1972; Kibinge et al., 2014). We calculated an additional parameter, end-to-end residue length, using a 6-31G* basis set Hartree-Fock calculation in SPARTAN '14 (Wavefunction). We choose to use $\mathrm{IC}_{40}$ or $\mathrm{IC}_{30}$ so that the values calculated remained within the limits of our experimental data (Fig. $5 A 1, A 2$ ) because many of our dose-response studied failed to reach $100 \%$ inhibition at $1 \mathrm{~mm}$ menthol. We obtained a satisfactory relation when we compared the end-to-end length of residues with the $\mathrm{IC}_{40}$ of (-)-menthol; the correlation coefficient was 0.69 (Fig. 7A1). For (+)-menthol $\left(\mathrm{IC}_{30}\right)$, we observed a correlation coefficient of 0.74 (Fig. 7A2). Thus, the potency of either stereoisomer of menthol exhibited a strong correlation with residue end-to-end length. We observed similar correlations when we compared the $\mathrm{IC}_{40}$ or $\mathrm{IC}_{30}$ of (-)-menthol and (+)-menthol, respectively, to residue volume (Fig. 7B1,B2).

Interestingly, previous data show that the $\mathrm{EC}_{50}$ of agonists depends strongly on polarity, a different property of the side chain at the 9' position (Kearney et al., 1996; Kosolapov et al., 2000). To test whether polarity is a factor for menthol-induced inhibition, we incorporated
O-methyl-threonine (O-Me-Thr) at the 9' position. The end-to-end length of O-Me-Thr is just $0.41 \AA$ longer than isoleucine ( 3.55 vs $3.14 \AA$ ), but because of the oxygen instead of a methylene unit in the side chain, O-Me-Thr is substantially more polar than isoleucine. If polarity at the 9' position is important for menthol inhibition, we would expect to measure a meaningful difference in the concentration-response curve for menthol inhibition at these two mutants. We observed that the concentration-response relationships overlapped when comparing $\alpha 4\left[\right.$ [' $\left.\left.9^{\prime}\right]\right] \beta 2$ to its O-Me-Thr variant (Fig. 7D). This suggests that menthol inhibition does not depend on the polarity of the $9^{\prime}$ side chain.

Additionally, we fitted the $\mathrm{IC}_{40}$ or $\mathrm{IC}_{30}$ values for (-)menthol and $(+)$-menthol, respectively, against the reduced AA index (Kibinge et al., 2014). The reduced AA index is a set of eight indices describing the variability of amino acids based on experimental results. The reduced $A A$ index is a subset of the $A A$ index after the elimination of redundancies. We found that the end-toend residue length and residue volume had more meaningful correlations than any parameter in the reduced AA index.

The two stereoisomers of menthol inhibit $\alpha 7 \mathrm{nAChRs}$ with similar $I_{50}$ values, but differences have been observed on the $\mathrm{GABA}_{\mathrm{A}}$ receptors, biomembrane models, and mouse odorant receptors (Corvalán et al., 2009; Ashoor et al., 2013b; Takai and Touhara, 2015; Gusain et al., 2017). To further compare the potency of (-)menthol and (+)-menthol on $\alpha 4 \beta 2$ nAChRs, we compared the percentage inhibition by $100 \mu \mathrm{M}$ menthol along with the $I_{50}$ and $\mathrm{plC}_{30}$ values on the $10\left(\alpha 4[\text { L9'X] })_{2}(\beta 2)_{3}\right.$ $\mathrm{nAChRs}$ and wild-type $(\alpha 4)_{3}(\beta 2)_{2} \mathrm{nAChR}$ (Fig. 5C,D1,D2). These scatterplots show either a comparison of the inhibition data (Fig. 5D1) or comparison to a logarithmic transformation (Fig. 5D2). We excluded the $\mathrm{IC}_{50}$ values for $\left(\alpha 4\left[\text { L9'A }^{\prime}\right)_{2}(\beta 2)_{3}\right.$ because we failed to observe inhibition of $50 \%$ of the control response. The data extend the experiments on wild-type nAChRs (Fig. 4), which showed modestly less inhibition by the (+) stereoisomer: (+)-menthol was on average $25 \%$ less potent than $(-)$-menthol (Fig. $5 D 1, D 2)$.

\section{Discussion}

Throughout the history of menthol-flavored tobacco products, various methods have been used to obtain the menthol used in cigarette production. Isolations from nat- 
Table 7: $\mathrm{IC}_{50}$ values for mutant $\alpha 4 \beta 2$ nAChRs

\begin{tabular}{|c|c|c|c|c|}
\hline Motivation & Mutant & $\mathrm{IC}_{50}(\mu \mathrm{M}(-)$-menthol $) \pm \mathrm{SEM}$ & Hill coefficient \pm SEM & Maximum inhibition (\%) \\
\hline WT-LS & $(\alpha 4[w t])_{3}(\beta 2[w t])_{2}$ & $33.7 \pm 1.16$ & $0.952 \pm 0.04$ & 95 \\
\hline WT-HS & $(\alpha 4[w t])_{2}(\beta 2[w t])_{3}$ & $33.9 \pm 7.40$ & $0.481 \pm 0.1$ & 71 \\
\hline WT- $\alpha 5$ & $\alpha 5[\mathrm{wt}](\alpha 4[\mathrm{wt}] \beta 2[\mathrm{wt}])_{2}$ & $51.0 \pm 9.06$ & $0.593 \pm 0.2$ & 53 \\
\hline $9^{\prime}$ residue & $(\alpha 4[\text { L9'A }])_{2}(\beta 2[w t])_{3}$ & $114 \pm 152$ & $0.779 \pm 0.2$ & 45 \\
\hline 9' residue & $\left(\alpha 4[\text { L9'S] })_{2}(\beta 2[w t])_{3}\right.$ & $514 \pm 361$ & $0.740 \pm 0.1$ & 65 \\
\hline $9^{\prime}$ residue & $\left(\alpha 4\left[\mathrm{Lg}^{\prime} \mathrm{l}\right]\right)_{2}(\beta 2[\mathrm{wt}])_{3}$ & $97.3 \pm 38.5$ & $0.836 \pm 0.2$ & 79 \\
\hline $9^{\prime}$ residue & $\left(\alpha 4[\text { L9'T] })_{2}(\beta 2[w t])_{3}\right.$ & $717 \pm 770$ & $0.946 \pm 0.3$ & 59 \\
\hline $9^{\prime}$ residue & $(\alpha 4[\text { L9' } \mathrm{Q}])_{2}(\beta 2[\mathrm{wt}])_{3}$ & $165 \pm 28.1$ & $1.03 \pm 0.1$ & 81 \\
\hline $9^{\prime}$ residue & $\left(\alpha 4[\text { LG'C] })_{2}(\beta 2[w t])_{3}\right.$ & $306 \pm 173$ & $0.744 \pm 0.1$ & 65 \\
\hline $9^{\prime}$ residue & $\left.\alpha 4\left[\mathrm{Lg}^{\prime} \mathrm{F}\right]\right)_{2}(\beta 2[\mathrm{wt}])_{3}$ & $211 \pm 75.6$ & $1.01 \pm 0.1$ & 72 \\
\hline 9' residue & $\left(\alpha 4\left[\mathrm{Lg}^{\prime} \mathrm{W}^{\prime}\right]\right)_{2}(\beta 2[\mathrm{wt}])_{3}$ & $28.8 \pm 3.26$ & $0.917 \pm 0.1$ & 87 \\
\hline GABA & $(\alpha 4[\mathrm{~L} 376 \mathrm{~W}])_{3}(\beta 2[\mathrm{wt}])_{2}$ & $17.4 \pm 43.2$ & $2.38 \pm 1.6$ & 92 \\
\hline $\mathrm{MD}$ & $(\alpha 4[\mathrm{~V} 356 \mathrm{~A}])_{3}(\beta 2[\mathrm{wt}])_{2}$ & $29.6 \pm 11.0$ & $0.631 \pm 0.2$ & 80 \\
\hline GABA & $(\alpha 4[\mathrm{wt}])_{3}(\beta 2[\mathrm{M} 305 \mathrm{~W}])_{2}$ & $70.6 \pm 29.9$ & $0.872 \pm 0.2$ & 90 \\
\hline MD & $(\alpha 4[w t])_{3}(\beta 2[\mathrm{~W} 355 \mathrm{~L}])_{2}$ & $28.8 \pm 24.6$ & $0.589 \pm 0.4$ & 80 \\
\hline MD & $(\alpha 4[\mathrm{~W} 363 \mathrm{~L}])_{3}(\beta 2[\mathrm{wt}])_{2}$ & $42.7 \pm 9.37$ & $1.02 \pm 0.2$ & 96 \\
\hline TRPM8 & $(\alpha 4[\mathrm{~L} 383 \mathrm{~A}])_{3}(\beta 2[\mathrm{wt}])_{2}$ & $27.9 \pm 4.97$ & $0.828 \pm 0.1$ & 96 \\
\hline TRPM8 & $(\alpha 4[\mathrm{wt}])_{3}(\beta 2[\mathrm{R} 299 \mathrm{~A}])_{2}$ & $52.0 \pm 5.89$ & $1.30 \pm 0.2$ & 96 \\
\hline MD & $(\alpha 4[\mathrm{I} 357 \mathrm{~A}])_{3}(\beta 2[\mathrm{wt}])_{2}$ & $31.4 \pm 6.23$ & $1.30 \pm 0.3$ & 94 \\
\hline MD & $(\alpha 4[\mathrm{~W} 363 \mathrm{~L}])_{3}(\beta 2[\mathrm{~W} 355 \mathrm{~L}])_{2}$ & $28.4 \pm 6.96$ & $0.866 \pm 0.2$ & 91 \\
\hline ADNFLE & $\left(\alpha 4\left[\mathrm{~S} 6^{\prime} \mathrm{F}\right]\right)_{3}(\beta 2[\mathrm{wt}])_{2}$ & $32.3 \pm 6.05$ & $1.19 \pm 0.3$ & 95 \\
\hline MD & $(\alpha 4[\mathrm{~F} 299 \mathrm{~A}])_{3}(\beta 2[\mathrm{wt}])_{2}$ & $20.4 \pm 10.4$ & $0.548 \pm 0.2$ & 93 \\
\hline $9^{\prime}$ residue & $\left(\alpha 4\left[\mathrm{Lg} \mathrm{g}^{\prime} \mathrm{O}-\mathrm{Me}-\mathrm{Thr}\right]\right)_{3}(\beta 2[\mathrm{wt}])_{2}$ & $135.9 \pm 20.9$ & $0.883 \pm 0.7$ & 79 \\
\hline GABA & $(\alpha 4[w t])_{3}(\beta 2[L 282 W])_{2}$ & $26.1 \pm 5.40$ & $0.883 \pm 0.1$ & 97 \\
\hline GABA & $(\alpha 4[\mathrm{wt}])_{3}(\beta 2[\mathrm{~V} 360 \mathrm{~W}])_{2}$ & $16.7 \pm 1.37$ & $1.08 \pm 0.09$ & 96 \\
\hline ADNFLE & $(\alpha 4[\mathrm{wt}])_{3}(\beta 2[\mathrm{~V} 287 \mathrm{~L}])_{2}$ & $17.0 \pm 5.67$ & $0.766 \pm 0.2$ & 89 \\
\hline Docking & $(\alpha 4[\mathrm{G} 281 \mathrm{~A}, \mathrm{~V} 236 \mathrm{~A}])_{3}(\beta 2[\mathrm{wt}])_{2}$ & $11.0 \pm 0.767$ & $0.958 \pm 0.06$ & 96 \\
\hline Docking & $(\alpha 4[\mathrm{wt}])_{3}(\beta 2[\mathrm{I} 218 \mathrm{~A}, \mathrm{~L} 257 \mathrm{~A}])_{2}$ & $23.0 \pm 2.68$ & $1.57 \pm 0.3$ & 99 \\
\hline Docking + GABA & $(\alpha 4[\mathrm{G} 281 \mathrm{~A}, \mathrm{~V} 236 \mathrm{~A}])_{3}(\beta 2[\mathrm{M} 368 \mathrm{~W}])_{2}$ & $59.5 \pm 15.2$ & $0.891 \pm 0.2$ & 95 \\
\hline GABA & $(\alpha 4[\mathrm{wt}])_{3}(\beta 2[\mathrm{Y} 275 \mathrm{~W}])_{2}$ & $21.7 \pm 5.21$ & $1.06 \pm 0.2$ & 97 \\
\hline GABA & $(\alpha 4[\mathrm{wt}])_{3}(\beta 2[\mathrm{M} 368 \mathrm{~W}])_{2}$ & $57.8 \pm 8.07$ & $0.865 \pm 0.09$ & 93 \\
\hline \# 9'A & $\alpha 5\left[\mathrm{~V} 9^{\prime} \mathrm{A}\right](\alpha 4[\mathrm{wt}] \beta 2[\mathrm{wt}])_{2}$ & $1750 \pm 3360$ & $0.907 \pm 0.3$ & 36 \\
\hline ADNFLE & $\left(\alpha 4\left[\mathrm{~S} 10^{\prime} \mathrm{L}\right]\right)_{3}(\beta 2[\mathrm{wt}])_{2}$ & $29.4 \pm 4.32$ & $1.39 \pm 0.2$ & 97 \\
\hline $\mathrm{MD}+\mathrm{GABA}$ & $(\alpha 4[\mathrm{~F} 299 \mathrm{~W}, \mathrm{~L} 376 \mathrm{~W}])_{3}(\beta 2[\mathrm{M} 368 \mathrm{~W}])_{2}$ & $107 \pm 7.07$ & $1.07 \pm 0.06$ & 94 \\
\hline MD & $(\alpha 4[\mathrm{~F} 299 \mathrm{~W}])_{3}(\beta 2[\mathrm{wt}])_{2}$ & $32.5 \pm 9.35$ & $0.604 \pm 0.09$ & 87 \\
\hline $\mathrm{MD}+\mathrm{GABA}$ & $(\alpha 4[\mathrm{~L} 376 \mathrm{~W}])_{3}(\beta 2[\mathrm{M} 368 \mathrm{~W}])_{2}$ & $107 \pm 29.6$ & $0.890 \pm 0.2$ & 87 \\
\hline $9^{\prime}$ residue & $\left(\alpha 4\left[\mathrm{Lg}^{\prime} \mathrm{M}\right]\right)_{3}(\beta 2[\mathrm{wt}])_{2}$ & $39.2 \pm 7.98$ & $0.848 \pm 0.09$ & 83 \\
\hline $\mathrm{MD}+\mathrm{GABA}$ & $(\alpha 4[\mathrm{~F} 299 \mathrm{~W}])_{3}(\beta 2[\mathrm{M} 368 \mathrm{~W}])_{2}$ & $92.5 \pm 36.8$ & $0.777 \pm 0.2$ & 79 \\
\hline 9 residue & $\left(\alpha 4\left[\mathrm{Lg}^{\prime} \mathrm{M}\right]\right)_{2}(\beta 2[\mathrm{wt}])_{3}$ & $26.6 \pm 1.90$ & $1.04 \pm 0.07$ & 91 \\
\hline MD & $(\alpha 4[\mathrm{~V} 356 \mathrm{~W}])_{3}(\beta 2[\mathrm{wt}])_{2}$ & $52.6 \pm 43.6$ & $0.599 \pm 0.2$ & 70 \\
\hline \# 9'A & $(\alpha 4[w t])_{3}\left(\beta 2\left[\text { L9'A }^{\prime}\right)_{2}\right.$ & $1920 \pm 9620$ & $0.807 \pm 0.6$ & 38 \\
\hline 9 residue & $\left(\alpha 4\left[\text { L9 }^{\prime}\right]\right)_{3}(\beta 2[w t])_{2}$ & $127 \pm 29.1$ & $0.947 \pm 0.1$ & 84 \\
\hline $9^{\prime}$ residue & $(\alpha 4[w t])_{2}\left(\beta 2\left[\mathrm{Lg}^{\prime} \mathrm{A}\right]\right)_{3}$ & $3030 \pm 2480$ & $0.832 \pm 0.8$ & 31 \\
\hline ACh binding site & $(\alpha 4[\mathrm{H} 116 \mathrm{~V}, \mathrm{Q} 124 \mathrm{~F}, \mathrm{~T} 126 \mathrm{~L}])_{3}(\beta 2[\mathrm{wt}])_{2}$ & $64.4 \pm 2.09$ & $1.20 \pm 0.05$ & 90 \\
\hline Intra-subunit & $(\alpha 4[\mathrm{C} 233 \mathrm{~A}])_{3}(\beta 2[\mathrm{wt}])_{2}$ & $46.1 \pm 6.43$ & $1.53 \pm 0.3$ & 98 \\
\hline Intra-subunit & $(\alpha 4[\mathrm{~T} 235 \mathrm{~A}])_{3}(\beta 2[\mathrm{wt}])_{2}$ & $66.6 \pm 8.03$ & $1.60 \pm 0.3$ & 97 \\
\hline Intra-subunit & $(\alpha 4[\mathrm{~V} 236 \mathrm{~A}])_{3}(\beta 2[\mathrm{wt}])_{2}$ & $58.9 \pm 10.0$ & $1.79 \pm 0.4$ & 91 \\
\hline Intra-subunit & $(\alpha 4[\mathrm{G} 281 \mathrm{~F}])_{3}(\beta 2[w \mathrm{wt}])_{2}$ & $108 \pm 19.1$ & $1.14 \pm 0.2$ & 99 \\
\hline Intra-subunit & $(\alpha 4[\mathrm{~S} 232 \mathrm{~A}])_{3}(\beta 2[\mathrm{wt}])_{2}$ & $92.0 \pm 26.7$ & $1.64 \pm 0.7$ & 92 \\
\hline Intra-subunit & $(\alpha 4[\mathrm{G} 281 \mathrm{~A}])_{3}(\beta 2[\mathrm{wt}])_{2}$ & $25.6 \pm 1.43$ & $1.49 \pm 0.1$ & 99 \\
\hline Near Cys Loop & $(\alpha 4[\mathrm{E} 52 \mathrm{~L}])_{3}(\beta 2[\mathrm{wt}])_{2}$ & $22.7 \pm 1.67$ & $0.969 \pm 0.07$ & 96 \\
\hline Near Cys loop & $(\alpha 4[\mathrm{E} 182 \mathrm{Q}])_{3}(\beta 2[\mathrm{wt}])_{2}$ & $24.3 \pm 0.593$ & $1.23 \pm 0.04$ & 81 \\
\hline Near Cys loop & $(\alpha 4[\mathrm{wt}])_{3}(\beta 2[\mathrm{~S} 44 \mathrm{~A}])_{2}$ & $59.9 \pm 5.09$ & $2.74 \pm 0.6$ & 94 \\
\hline Channel pore & $(\alpha 4[\mathrm{~L} 265 \mathrm{~A}])_{3}(\beta 2[\mathrm{wt}])_{2}$ & $21.1 \pm 3.06$ & $1.16 \pm 0.2$ & 97 \\
\hline Channel pore & $(\alpha 4[\mathrm{wt}])_{3}(\beta 2[\mathrm{~L} 257 \mathrm{~A}])_{2}$ & $74.8 \pm 15.6$ & $1.36 \pm 0.3$ & 98 \\
\hline Interfacial & $(\alpha 4[\mathrm{~F} 286 \mathrm{~A}])_{3}(\beta 2[\mathrm{wt}])_{2}$ & $54.2 \pm 19.9$ & $0.927 \pm 0.3$ & 87 \\
\hline Interfacial & $(\alpha 4[w t])_{3}(\beta 2[\mid 218 \mathrm{~A}])_{2}$ & $60.9 \pm 7.63$ & $1.12 \pm 0.1$ & 99 \\
\hline Interfacial & $(\alpha 4[\mathrm{G} 281 \mathrm{~A}])_{3}(\beta 2[\mathrm{I} 218 \mathrm{~A}])_{2}$ & $23.8 \pm 1.58$ & $2.25 \pm 0.3$ & 99 \\
\hline
\end{tabular}

WT-LS, Wild-type $\alpha 4 \beta 2$ receptor with the low sensitivity stoichiometry; WT-HS, wild-type $\alpha 4 \beta 2$ receptor with the high sensitivity stoichiometry; WT- $\alpha 5$, wildtype $\alpha 4 \beta 2$ receptor with $\alpha 5$ in the auxiliary position; 9' residue, a mutant at the '9' position to probe the effects of mutations at this site; GABA, analogous site for the menthol binding site in the GABA receptor; MD, molecular dynamics predicted position; TRPM8, analogous site for the menthol binding site on the TRPM8 receptor; ANDFLE, a mutant that is found in ADNFLE patients; Docking, position predicted by preliminary docking studies; \#L9'A, mutant made to probe the effects that the number of 9'A mutations has on the effects of menthol; ACh Binding Site, the putative ACh binding site; Intra-subunit, site between subunits in the transmembrane domain of $\alpha 4 \beta 2$; Near Cys Loop, site that is near the Cys loop of $\alpha 4 \beta 2$; Channel Pore, site that is in the channel pore of $\alpha 4 \beta 2$; Interfacial, a site on the transmembrane domain of a single subunit that faces toward the other transmembrane domain helices on the same subunit. 
A

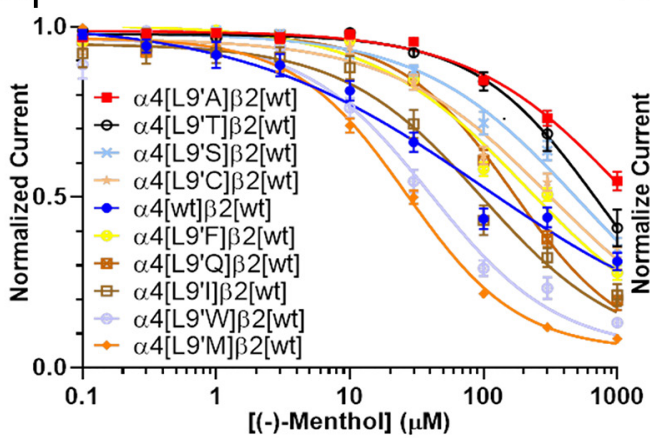

B

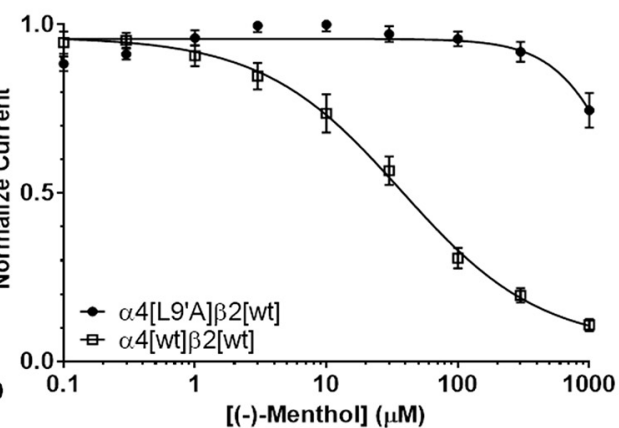

$\mathbf{A}_{2}$

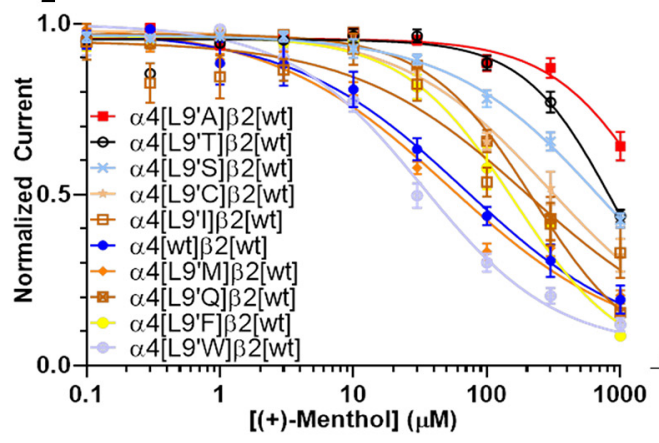

C

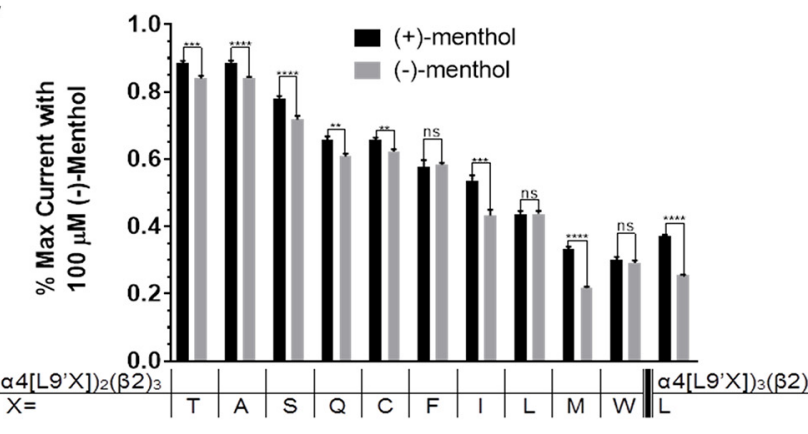

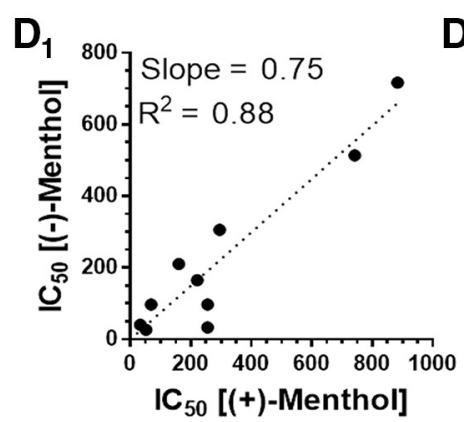

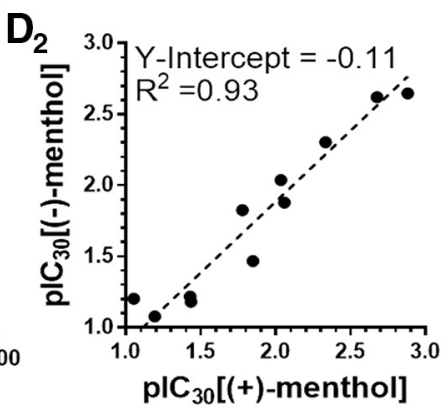

Figure 5. $\alpha 4$ L9' mutations probe the putative binding site of menthol. $\boldsymbol{A}_{1}, \boldsymbol{A}_{2}$, Concentration-response curves for menthol against $(\alpha 4[\mathrm{Lg} X])_{2}(\beta 2)_{3}$, where $\mathrm{X}$ is any amino acid. Each receptor is activated by its respective $\mathrm{EC}_{50}$ dose of $A C h\left(\mathrm{~A}_{1}\right)(-)$-menthol and $\left(\mathrm{A}_{2}\right)$ (+)-menthol. B. Concentration-response curves for $\left(\alpha 4\left[\mathrm{Lg} \mathrm{X}^{\prime}\right]_{3}(\beta 2)_{2}\right.$ and $(\alpha 4)_{3}(\beta 2)_{2}$ using $1 \mu \mathrm{M} \mathrm{ACh}$. $\boldsymbol{C}$, Comparing the percentage maximum current induced when the oocyte is exposed to $100 \mu \mathrm{m}$ menthol. $* p<0.05 ; * * p<0.01 ; * * * p<0.005 ; * * * * p<0.001$. Exact $p$ values are provided in extended data (Fig. 5-1). $\boldsymbol{D}_{1}$, Comparing the $\mathrm{IC}_{50}$ values. In this plot, $\left(\alpha 4\left[\mathrm{Lg} \mathrm{g}^{\prime} \mathrm{A}\right)_{2}(\beta 2)_{3}\right.$ is omitted because at no tested concentration of menthol was the receptor inhibited $50 \%$. $\boldsymbol{D}_{2}$, Plot of $\mathrm{IC}_{30}$ values comparing $(+)$-menthol and $(-)$-menthol; $n=6-18$ oocytes.

ural sources (mint leaves and oils) primarily produce (-)menthol; most synthetic methods produce a racemic mixture of both (+)-menthol and (-)-menthol. The exception is the asymmetric synthesis developed by Ohkuma et al. (2000). We found that (+)-menthol and (-)-menthol exhibit different effects on $\alpha 4 \beta 2 \mathrm{nAChR}$ upregulation (Fig. 1). We also observed differences among the menthol stereoisomers in their ability to alter dopamine neuron firing frequency and excitability (Figs. 2, 3). Our previous investigations into the actions menthol used $( \pm)$-menthol (Henderson et al., 2016, 2017). Previous reports observed that ( \pm )-menthol by itself upregulated $\mathrm{nAChRs,} \mathrm{altered}$ dopamine neuron firing, enhanced the upregulation of nicotine-induced $\mathrm{nAChR}$ upregulation, and enhanced nicotine reward-related behavior. Because the present inves- tigation shows that $(+)$-menthol has no effect on nAChR upregulation and dopamine neuron excitability, we conclude that previous observations of long-term menthol exposure and its effect on nAChR upregulation and dopamine neuron excitability were likely caused primarily by (-)-menthol only.

Because of the contrast between the high concentration of menthol required for acute inhibition of $n A C h R s$ $(>30 \mu \mathrm{M})$ and the submicromolar effects on upregulation and dopamine neuron firing ( $\leq 500 \mathrm{~nm}$ ), it is likely that menthol acts via multiple targets. The simulations and data in this study strongly suggest that the acute inhibitory effect of menthol is mediated through its direct interaction with nAChRs at the $9^{\prime}$ leucine site within the TM2 region. In previous electrophysiological experiments, well 
A

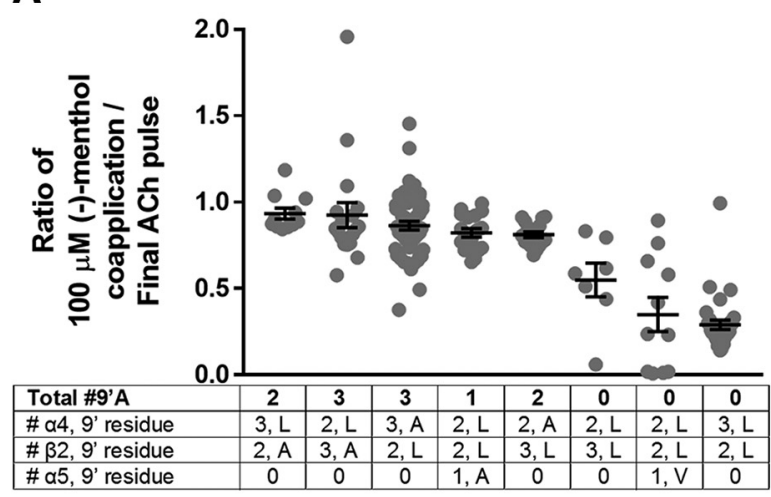

B

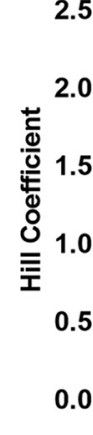

Receptors with Inhibition at $1000 \mu \mathrm{M}$ Menthol > 50\%

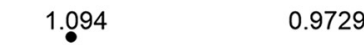

Figure 6. $\boldsymbol{A}$, The ratio of currents elicited by an $\mathrm{EC}_{50}$ concentration of $\mathrm{ACh}$ and $100 \mu \mathrm{m}$ menthol over the current elicited by $\mathrm{ACh}$ alone. Error bars represent the SEM; $n=7-33$ oocytes. $\boldsymbol{B}$, Average Hill coefficients for wild-type and all mutant $\alpha 4 \beta 2$ mutants tested $(p=$ $0.07)$. Error bars represent the SD; $n=7-39$ mutants

characterized $\mathrm{nAChR}$ blockers have permanent positive charges (e.g., QX-222) or can be protonated (e.g., mecamylamine) and bind near this site (at the $6^{\prime}$ and 10' positions) by approaching through the open pore (Charnet et al., 1990; Lester, 1992; Papke et al., 2013). However, other experiments suggest that uncharged, membrane-permeant blockers, such as deprotonated procaine, can bind to the $6^{\prime}$ and $10^{\prime}$ residues in closed channels by approaching through the membrane or through the receptor protein (Adams, 1977; Lester, 1992). The simulations in this study reinforce the concept that menthol approaches the $9^{\prime}$ site in closed $\alpha 4 \beta 2 \mathrm{nAChR}$ channels by approaching from the protein. Our simulations are uninformative about a possible approach from the membrane phase, because the parameters were adjusted to minimize accumulation in the membrane phase (see Materials and Methods).

The experiments also show that (-)-menthol is only slightly ( 25\%) more effective than (+)-menthol at inhibiting WT receptors (Fig. 4). This difference would be neglected if the dataset contained only WT receptors, but it is consistent and significant when assessed over a series of $9^{\prime}$ mutations that encompass a nearly 1000 -fold range of sensitivities to menthol block (Fig. 5D1,D2). S(+)mecamylamine is a slightly more potent blocker than $\mathrm{R}(-)$ mecamylamine over a series of nAChR subtypes (Papke et al., 2013). These differences between stereoisomers as nAChR blockers are markedly less than the threefold to fourfold greater potency of $(-)$ menthol versus (+)-menthol at TRPM8 channels (Sherkheli et al., 2010).

The submicromolar chronic effects of menthol may result from a non-nAChR target. In addition to its actions on $n A C h R s$, menthol acts as a positive modulator on $\mathrm{GABA}_{\mathrm{A}}$ and glycine receptors and a noncompetitive antagonist of 5- $\mathrm{HT}_{3}$ receptors (Hall et al., 2004; Ashoor et al., 2013a). Menthol has well studied actions on TRP family proteins, especially TRPM8 and TRPA1 (Oz et al., 2017). Menthol also acts on other targets ( $\mathrm{Oz}$ et al., 2017). Therefore, while menthol has acute actions on nAChRs (noncompetitive inhibition) through an allosteric interaction at the 9' site, its effects on nAChR upregulation and dopamine neuron excitability may be caused by another protein target. Previous investigators suggested that menthol acts as a chemical chaperone (Henderson et al., 2016), in part because menthol enhanced the ER export of nAChRs. This designation has both analogies and differences with the pharmacological chaperoning of nAChRs by nicotine (Kuryatov et al., 2005; Srinivasan et al., 2011). Menthol may indeed be a chemical chaperone for nAChRs; but, given its ability to bind to many proteins of interest, we must consider that the enhancement of ER export by menthol may arise from its actions on a non$\mathrm{nAChR}$ target related to anterograde trafficking of proteins or membranes.

As discussed earlier, menthol enhances nicotine reward (Henderson et al., 2017) and nicotine reinforcement (Wang et al., 2014; Biswas et al., 2016) in rodent models and produces poorer cessation rates in human smokers (Food and Drug Administration, 2012). Although the predominant form present in current tobacco products is (-)-menthol, the composition of menthol used in many tobacco products is presently neither disclosed nor regulated. For this reason, it is important to understand how both (+)-menthol and (-)-menthol alter the nAChRs on dopamine neurons that are involved in nicotine reward and reinforcement. This is especially important given that the ENDS market will become subject to systematic regulatory control by the Food and Drug Administration. Our data suggest that menthol exhibits a stereospecific effect only with low-dose, long-term exposure. We hypothesize that of the two primary menthol stereoisomers, only (-)menthol plays a role in enhancing nicotine reward through nAChRs on dopamine neurons. We do not yet suggest that (+)-menthol lacks any role in nicotine reward. GABA neurons in the VTA and SNr play an important role in nicotine reward as their disinhibition plays a critical role in the ability of nicotine to drive enhancements, dopamine neuron excitability, and dopamine release (Mansvelder et al., 2002; Nashmi et al., 2007). Menthol does act as a positive allosteric modulator of $\mathrm{GABA}_{\mathrm{A}}$ receptors and $(+)$ menthol is more potent than (-)-menthol on these receptors (Hall et al., 2004; Corvalán et al., 2009). Given that stereospecific effects of menthol have been observed with $\mathrm{nAChRs}$ and GABA receptors (both important targets for nicotine reward), there is a continued need to under- 

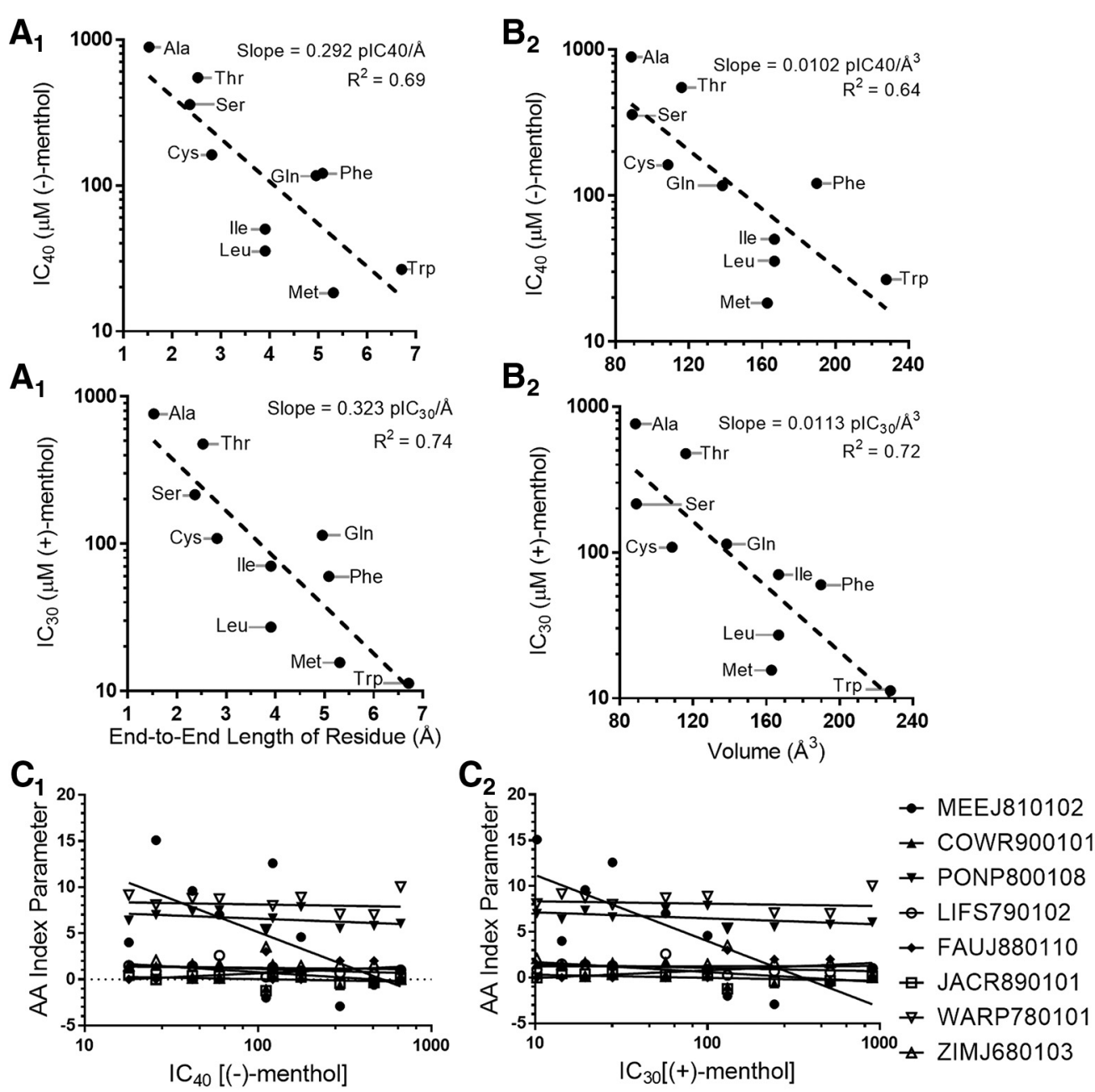

D
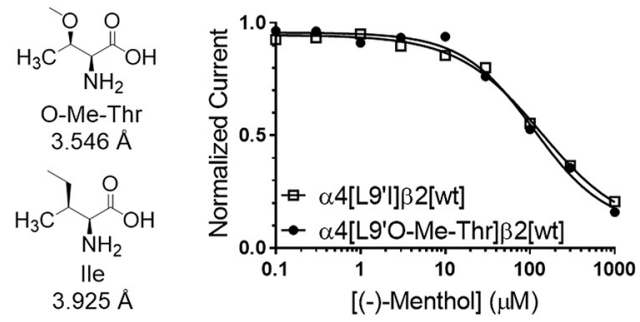

Figure 7. Potency of menthol depends on L9' residue size. $\boldsymbol{A}_{\mathbf{1}}-\boldsymbol{B}_{\mathbf{2}}$, Plot of $\mathrm{IC}_{40}$ for $(-)$-menthol versus residue length $\left(\boldsymbol{A}_{\mathbf{1}}\right)$ or residue volume $\left(\boldsymbol{B}_{1}\right)$ and plot of $\mathrm{IC}_{30}$ for $(+)$-menthol versus residue length $\left(\boldsymbol{A}_{2}\right)$ or residue volume $\left(\boldsymbol{B}_{2}\right)$. $\boldsymbol{C}_{1}$, Fitting the $I C_{40}$ values for $(-)$-menthol against the reduced $\mathrm{AA}$ index. $\boldsymbol{C}_{2}$, Fitting the $\mathrm{IC}_{30}$ values for $(+)$-menthol against the reduced $\mathrm{AA}$ index. $R^{2}$ values in $\boldsymbol{C}_{1}$ and $\boldsymbol{C}_{2}$ for each parameter are indicated in extended Figures 7-1 and 7-2. $\boldsymbol{D}$, Concentration-response relationship for (-)-menthol on $\left(\alpha 4\left[\mathrm{Lg}^{\prime} \mathrm{I}\right]\right)_{3}(\beta 2)_{2}$ and $\left(\alpha 4\left[\mathrm{Lg}^{\prime} \mathrm{O}-\mathrm{Me}-\mathrm{Thr}\right]\right)_{3}(\beta 2)_{2} \mathrm{nAChRs}$. Structures of the two amino acids are shown to the left along with their end-to-end length; $n=7-18$ oocytes.

stand their distinct pharmacology and how it alters the actions of nicotine on midbrain neurons.

Given the reduced effect (+)-menthol exhibits on dopamine neurons, would public health benefit from availability of combustible products in which $(+)$ menthol replaces (-)-menthol? Because $(+)$-menthol is also less effective at activating TRPM8, (+)mentholated products might also less effectively provide the characteristic cooling sensation. Smokers might therefore continue to prefer tobacco flavored with (-)-menthol (Sherkheli et al., 2010). We also have no information about stereospecificity of TRPA1 activation by either menthol or nicotine (Talavera et al., 2009). This report, and others (Alsharari et al., 2015; Biswas et al., 2016; Fan et al., 2016; Henderson et al., 2016, 2017), provide evidence both that (-)-menthol plays a role in enhancing the addiction to nicotine, and also that simply substituting $(+)$-menthol for $(-)$-menthol in 
combustible tobacco products may not be the correct strategy for harm reduction.

\section{References}

Adams PR (1977) Voltage jump analysis of procaine action at frog end-plate. J Physiol 268:291-318. CrossRef Medline

Ahijevych K, Garrett BE (2010) The role of menthol in cigarettes as a reinforcer of smoking behavior. Nicotine Tob Res 12:S110-S116. CrossRef Medline

Alsharari SD, King JR, Nordman JC, Muldoon PP, Jackson A, Zhu AZX, Tyndale RF, Kabbani N, Damaj MI (2015) Effects of menthol on nicotine pharmacokinetic, pharmacology and dependence in mice. PLoS One 10:e0137070. CrossRef Medline

Arcario MJ, Mayne CG, Tajkhorshid E (2017) A membraneembedded pathway delivers general anesthetics to two interacting binding sites in the Gloeobacter violaceus ion channel. J Biol Chem 292:9480-9492. CrossRef Medline

Ashoor A, Nordman JC, Veltri D, Yang KHS, Shuba Y, Al Kury L, Sadek B, Howarth FC, Shehu A, Kabbani N, Oz M (2013a) Menthol inhibits 5-HT3 receptor-mediated currents. J Pharmacol Exp Ther 347:398-409. CrossRef Medline

Ashoor A, Nordman JC, Veltri D, Yang KH, Al Kury L, Shuba Y, Mahgoub M, Howarth FC, Sadek B, Shehu A, Kabbani N, Oz M (2013b) Menthol binding and inhibition of $\alpha 7$-nicotinic acetylcholine receptors. PLoS One 8:e67674. CrossRef Medline

Biswas L, Harrison E, Gong YZ, Avusula R, Lee J, Zhang MY, Rousselle T, Lage J, Liu X (2016) Enhancing effect of menthol on nicotine self-administration in rats. Psychopharmacology 233: 3417-3427. CrossRef Medline

Bottaro S, Lindorff-Larsen K (2018) Biophysical experiments and biomolecular simulations: a perfect match? Science 361:355-360. CrossRef Medline

Brannigan G, LeBard DN, Hénin J, Eckenhoff RG, Klein ML (2010) Multiple binding sites for the general anesthetic isoflurane identified in the nicotinic acetylcholine receptor transmembrane domain. Proc Natl Acad Sci U S A 107:14122-14127. CrossRef Medline

Centers for Disease Control and Prevention (2016) Tobacco use among middle and high school students-United States, 20112015. MMWR Morb Mortal Wkly Rep 65:361-367. CrossRef Medline

Charnet P, Labarca C, Leonard RJ, Vogelaar NJ, Czyzyk L, Gouin A, Davidson N, Lester HA (1990) An open-channel blocker interacts with adjacent turns of alpha-helices in the nicotinic acetylcholine receptor. Neuron 4:87-95. CrossRef Medline

Chen C, Luo W, Isabelle LM, Gareau KD, Pankow JF (2011) The stereoisomers of menthol in selected tobacco products. A brief report. Nicotine Tob Res 13:741-745. CrossRef Medline

Corvalán NA, Zygadlo JA, García DA (2009) Stereo-selective activity of menthol on $\operatorname{GABA}(A)$ receptor. Chirality $21: 525-530$. CrossRef Medline

D'Silva J, Boyle RG, Lien R, Rode P, Okuyemi KS (2012) Cessation outcomes among treatment-seeking menthol and nonmenthol smokers. Am J Prev Med 43:S242-S248. CrossRef

Dalton JA, Gómez-Santacana X, Llebaria A, Giraldo J (2014) Computational analysis of negative and positive allosteric modulator binding and function in metabotropic glutamate receptor 5 (in)activation. J Chem Inf Model 54:1476-1487. CrossRef

Darden T, York D, Pedersen L (1993) Particle mesh Ewald: an $N \cdot \log (N)$ method for Ewald sums in large systems. J Chem Phys 98:10089-10092. CrossRef

Dash B, Li MD, Lukas RJ (2014) Roles for N-terminal extracellular domains of nicotinic acetylcholine receptor (nAChR) $\beta 3$ subunits in enhanced functional expression of mouse $\alpha 6 \beta 2 \beta 3$ - and $\alpha 6 \beta 4 \beta 3$ nAChRs. J Biol Chem 289:28338-28351. CrossRef Medline

Drenan RM, Nashmi R, Imoukhuede P, Just H, McKinney S, Lester HA (2008) Subcellular trafficking, pentameric assembly, and subunit stoichiometry of neuronal nicotinic acetylcholine receptors containing fluorescently labeled alpha6 and beta3 Subunits. Mol Pharmacol 73:27-41. CrossRef Medline
Essmann U, Perera L, Berkowitz ML, Darden T, Lee H, Pedersen LG (1995) A smooth particle mesh Ewald method. J Chem Phys 103:8577-8593. CrossRef

Fan L, Balakrishna S, Jabba SV, Bonner PE, Taylor SR, Picciotto MR, Jordt SE (2016) Menthol decreases oral nicotine aversion in C57BL/6 mice through a TRPM8-dependent mechanism. Tob Control 25:ii50-ii54. CrossRef Medline

Food and Drug Administration (2012) Preliminary scientific evaluation of the possible public health effects of menthol versus nonmenthol cigarettes. Silver Spring, MD: Food and Drug Administration.

Gusain P, Ohki S, Hoshino K, Tsujino Y, Shimokawa N, Takagi M (2017) Chirality-dependent interaction of D- and L-menthol with biomembrane models. Membranes 7:13.

Ha MA, Smith GJ, Cichocki JA, Fan L, Liu YS, Caceres Al, Jordt SE, Morris JB (2015) Menthol attenuates respiratory irritation and elevates blood cotinine in cigarette smoke exposed mice. PLoS One 10:e0117128. CrossRef Medline

Hall AC, Turcotte CM, Betts BA, Yeung WY, Agyeman AS, Burk LA (2004) Modulation of human GABA(A) and glycine receptor currents by menthol and related monoterpenoids. Eur $\mathrm{J}$ Pharmacol 506:9-16. CrossRef Medline

Hans M, Wilhelm M, Swandulla D (2012) Menthol suppresses nicotinic acetylcholine receptor functioning in sensory neurons via allosteric modulation. Chem Senses 37:463-469. CrossRef Medline

Heck JD (2010) A review and assessment of menthol employed as a cigarette flavoring ingredient. Food Chem Toxicol 48 [Suppl. 2]: S1-38. CrossRef Medline

Henderson BJ, Srinivasan R, Nichols WA, Dilworth CN, Gutierrez DF, Mackey EDW, McKinney S, Drenan RM, Richards Cl, Lester HA (2014) Nicotine exploits a COPI-mediated process for chaperonemediated up-regulation of its receptors. J Gen Physiol 143:51-66. CrossRef Medline

Henderson BJ, Wall TR, Henley BM, Kim CH, Nichols WA, Moaddel R, Xiao C, Lester HA (2016) Menthol alone upregulates midbrain $n A C h R s$, alters nAChR subtype stoichiometry, alters dopamine neuron firing frequency, and prevents nicotine reward. J Neurosci 36:2957-2974. CrossRef Medline

Henderson BJ, Wall TR, Henley BM, Kim CH, McKinney S, Lester HA (2017) Menthol enhances nicotine reward-related behavior by potentiating nicotine-induced changes in nAChR function, nAChR upregulation, and DA neuron excitability. Neuropsychopharmacology 42:2285-2291. CrossRef Medline

Humphrey W, Dalke A, Schulten K (1996) VMD: visual molecular dynamics. J Mol Graph Model 14:33-38. CrossRef Medline

Jo S, Kim T, lyer VG, Im W (2008) CHARMM-GUI: a web-based graphical user interface for CHARMM. J Comput Chem 29:18591865. CrossRef Medline

Jorgensen WL, Chandrasekhar J, Madura JD, Impey RW, Klein ML (1983) Comparison of simple potential functions for simulating liquid water. J Chem Phys 79:926-935. CrossRef

Kearney PC, Zhang HY, Zhong W, Dougherty DA, Lester HA (1996) Determinants of nicotinic receptor gating in natural and unnatural side chain structures at the M2 9' position. Neuron 17:1221-1229. CrossRef

Kibinge N, Ikeda S, Ono N, Altaf-UI-Amin M, Kanaya S (2014) Integration of residue attributes for sequence diversity characterization of terpenoid enzymes. Biomed Res Int 2014:753428. CrossRef Medline

Klauda JB, Venable RM, Freites JA, O'Connor JW, Tobias DJ, Mondragon-Ramirez C, Vorobyov I, MacKerell AD, Pastor RW (2010) Update of the CHARMM all-atom additive force field for lipids: validation on six lipid types. J Phys Chem B 114:78307843. CrossRef Medline

Kosolapov AV, Filatov GN, White MM (2000) Acetylcholine receptor gating is influenced by the polarity of amino acids at position $9^{\prime}$ in the M2 domain. J Membr Biol 174:191-197. CrossRef Medline

Kuryatov A, Luo J, Cooper J, Lindstrom J (2005) Nicotine acts as a pharmacological chaperone to up-regulate human alpha4beta2 
acetylcholine receptors. Mol Pharmacol 68:1839-1851. CrossRef Medline

Labarca C, Nowak MW, Zhang HY, Tang LX, Deshpande P, Lester HA (1995) Channel gating governed symmetrically by conserved leucine residues in the $\mathrm{M} 2$ domain of nicotinic receptors. Nature 376:514-516. CrossRef Medline

Lau BK, Vaughan CW (2014) Descending modulation of pain: the GABA disinhibition hypothesis of analgesia. Curr Opin Neurobiol 29:159-164. CrossRef Medline

Lester HA (1992) The permeation pathway of neurotransmitter-gated ion channels. Annu Rev Biophys Biomol Struct 21:267-292. CrossRef Medline

Mansvelder HD, Keath JR, McGehee DS (2002) Synaptic mechanisms underlie nicotine-induced excitability of brain reward areas. Neuron 33:905-919. CrossRef Medline

Marotta CB, Dilworth CN, Lester HA, Dougherty DA (2014) Probing the non-canonical interface for agonist interaction with an $\alpha 5$ containing nicotinic acetylcholine receptor. Neuropharmacology 77:342-349. CrossRef Medline

McCarthy WJ, Caskey NH, Jarvik ME, Gross TM, Rosenblatt MR, Carpenter C (1995) Menthol vs nonmenthol cigarettes: effects on smoking-behavior. Am J Public Health 85:67-72. CrossRef Medline

Morales-Perez CL, Noviello CM, Hibbs RE (2016) X-ray structure of the human $\alpha 4 \beta 2$ nicotinic receptor. Nature 538:411-415. CrossRef Medline

Nashmi R, Xiao C, Deshpande P, McKinney S, Grady SR, Whiteaker P, Huang Q, McClure-Begley T, Lindstrom JM, Labarca C, Collins AC, Marks MJ, Lester HA (2007) Chronic nicotine cell specifically upregulates functional alpha $4 *$ nicotinic receptors: basis for both tolerance in midbrain and enhanced long-term potentiation in perforant path. J Neurosci 27:8202-8218. CrossRef Medline

Nelson ME, Kuryatov A, Choi CH, Zhou Y, Lindstrom J (2003) Alternate stoichiometries of alpha4beta2 nicotinic acetylcholine receptors. Mol Pharmacol 63:332-341. CrossRef Medline

Ohkuma T, Ishii D, Takeno H, Noyori R (2000) Asymmetric hydrogenation of amino ketones using chiral $\mathrm{RuCl}_{2}$ (diphophine)(1,2diamine) complexes. J Am Chem Soc 122:6510-6511. CrossRef

Oz M, El Nebrisi EG, Yang KS, Howarth FC, AI Kury LT (2017) Cellular and molecular targets of menthol actions. Front Pharmacol 8:472. CrossRef Medline

Papke RL, Stokes C, Muldoon P, Imad Damaj M (2013) Similar activity of mecamylamine stereoisomers in vitro and in vivo. Eur $\mathrm{J}$ Pharmacol 720:264-275. CrossRef Medline

Phillips JC, Braun R, Wang W, Gumbart J, Tajkhorshid E, Villa E, Chipot C, Skeel RD, Kalé L, Schulten K (2005) Scalable molecular dynamics with NAMD. J Comput Chem 26:1781-1802. CrossRef Medline

Prinz H (2010) Hill coefficients, dose-response curves and allosteric mechanisms. J Chem Biol 3:37-44. CrossRef Medline

Richards Cl, Srinivasan R, Xiao C, Mackey EDW, Miwa JM, Lester HA (2011) Trafficking of alpha4* nicotinic receptors revealed by superecliptic phluorin: effects of a beta4 amyotrophic lateral sclerosis-associated mutation and chronic exposure to nicotine. $J$ Biol Chem 286:31241-31249. CrossRef Medline
Sánchez R, Sali A (1998) Large-scale protein structure modeling of the Saccharomyces cerevisiae genome. Proc Natl Acad Sci U S A 95:13597-13602. CrossRef Medline

Sell CS (2006) The chemistry of fragrances: from perfumer to consumer. Cambridge, UK: Royal Society of Chemistry.

Sherkheli MA, Vogt-Eisele AK, Bura D, Beltrán Márques LR, Gisselmann G, Hatt H (2010) Characterization of selective TRPM8 ligands and their structure activity response (S.A.R.) relationship. J Pharm Pharm Sci 13:242-253. CrossRef

Srinivasan R, Pantoja R, Moss FJ, Mackey EDW, Son CD, Miwa J, Lester HA (2011) Nicotine up-regulates $\alpha 4 \beta 2$ nicotinic receptors and ER exit sites via stoichiometry-dependent chaperoning. J Gen Physiol 137:59-79. CrossRef Medline

Srinivasan R, Henley BM, Henderson BJ, Indersmitten T, Cohen BN, Kim CH, McKinney S, Deshpande P, Xiao C, Lester HA (2016) Smoking-relevant nicotine concentration attenuates the unfolded protein response in dopaminergic neurons. J Neurosci 36:65-79. CrossRef Medline

Takai Y, Touhara K (2015) Enantioselective recognition of menthol by mouse odorant receptors. Biosci Biotechnol Biochem 79:19801986. CrossRef Medline

Talavera K, Gees M, Karashima Y, Meseguer VM, Vanoirbeek JA, Damann N, Everaerts W, Benoit M, Janssens A, Vennekens R, Viana F, Nemery B, Nilius B, Voets T (2009) Nicotine activates the chemosensory cation channel TRPA1. Nat Neurosci 12:12931299. CrossRef Medline

Tapia L, Kuryatov A, Lindstrom J (2007) Ca2+ permeability of the (alpha4)3(beta2)2 stoichiometry greatly exceeds that of (alpha4)2(beta2)3 human acetylcholine receptors. Mol Pharmacol 71:769-776. CrossRef Medline

Ton HT, Smart AE, Aguilar BL, Olson TT, Kellar KJ, Ahern GP (2015) Menthol enhances the desensitization of human $\alpha 3 \beta 4$ nicotinic acetylcholine receptors. Mol Pharmacol 88:256-264. CrossRef Medline

Vanommeslaeghe K, MacKerell AD (2012) Automation of the CHARMM general force field (CGenFF) I: bond perception and atom typing. J Chem Inf Model 52:3144-3154. CrossRef Medline

Vanommeslaeghe K, Hatcher E, Acharya C, Kundu S, Zhong S, Shim J, Darian E, Guvench O, Lopes P, Vorobyov I, MacKerell AD (2010) CHARMM general force field: a force field for drug-like molecules compatible with the CHARMM all-atom additive biological force fields. J Comput Chem 31:671-690. CrossRef Medline

Vanommeslaeghe K, Raman EP, MacKerell AD (2012) Automation of the CHARMM general force field (CGenFF) II: assignment of bonded parameters and partial atomic charges. J Chem Inf Model 52:3155-3168. CrossRef Medline

Wang TF, Wang B, Chen $\mathrm{H}$ (2014) Menthol facilitates the intravenous self-administration of nicotine in rats. Front Behav Neurosci 8:437. CrossRef Medline

Yu WB, He XB, Vanommeslaeghe K, MacKerell AD (2012) Extension of the CHARMM general force field to sulfonyl-containing compounds and its utility in biomolecular simulations. $\mathrm{J}$ Comput Chem 33:2451-2468. CrossRef Medline

Zamyatnin AA (1972) Protein volume in solution. Prog Biophys Mol Biol 24:107-123. CrossRef Medline 